\title{
Opposing roles of Granzymes $A$ and $B$ in the immune response to intestinal infection
}

Maud Vandereyken ${ }^{1}$, Amanpreet Singh Chawla ${ }^{1}$, Maykel Arias ${ }^{2,3}$, Llipsy Santiago ${ }^{2,3}$, Nicolas Wenner $^{4,5}$, Sarah J. Thomson ${ }^{6}$, Dina Dikovskaya ${ }^{1}$, Chi Nguyen $^{1}$, Marcela Garzón-Tituaña ${ }^{2}$, Jay C. D. Hinton ${ }^{4}$, Julian Pardo ${ }^{2,3}$, Mahima Swamy ${ }^{1,7}$ *

${ }^{1}$ MRC Protein Phosphorylation and Ubiquitylation Unit, University of Dundee, Dundee DD1 5EH, United Kingdom

${ }^{2}$ Fundación Instituto de Investigación Sanitaria Aragón (IIS Aragón), Biomedical Research Centre of Aragón (CIBA), 50009, Zaragoza, and CIBER en Enfermedades Infecciosas, Madrid, Spain.

${ }^{3}$ Departamento de Microbiología y Medicina Preventiva, Facultad de Medicina, Universidad de Zaragoza

${ }^{4}$ Department of Clinical Infection Microbiology \& Immunology, Institute of Infection, Veterinary \& Ecological Sciences, University of Liverpool, Liverpool, United Kingdom

${ }^{5}$ Current address: Biozentrum, University of Basel, Basel, Switzerland

${ }^{6}$ Biological Services and ${ }^{7}$ Cell Signalling and Immunology, School of Life Sciences, University of Dundee, Dundee DD1 5EH, United Kingdom

*Address correspondence to: Dr. Mahima Swamy m.swamy@dundee.ac.uk 


\section{SUMMARY}

The cytotoxic proteases Granzymes $A(G z m A)$ and B $(\mathrm{GzmB})$ are important components of the arsenal used by cytotoxic immune cells to kill virally infected/damaged cells. Until now, there has been limited evidence that GzmA/B proteins contribute to combating intracellular bacterial pathogens in mammals. Here, we find that the route of infection of the intracellular bacterial pathogen Salmonella enterica serovar Typhimurium reveals the distinct roles that Granzymes play in defending against bacterial infection. We used $\mathrm{Gzma}^{-/-} \mathrm{Gzmb} b^{-/-}$mice to discover that Granzymes are required to protect mice against oral infection with Salmonella. However, Granzymes do not play a role in systemic infection. We investigated the tissue-specific expression of Granzymes and determined that intestinal intraepithelial lymphocytes (IEL) are the only cell types that express Granzymes in healthy non-infected mice. In fact, IEL are sufficient to mediate the protective effects of Granzymes against Salmonella infection. Intriguingly, we found that GzmA and GzmB play opposing roles in Salmonella control, with GzmA being protective against infection whilst GzmB promoted infection. Both GzmA and GzmB proteins functioned independently of the pore-forming molecule Perforin, suggesting extracellular action. Our study reveals that IEL-expressed Granzymes play significant and distinct functions in host defense from oral bacterial infection. 
bioRxiv preprint doi: https://doi.org/10.1101/2021.11.07.467595; this version posted November 23, 2021. The copyright holder for this preprint (which was not certified by peer review) is the author/funder, who has granted bioRxiv a license to display the preprint in perpetuity. It is made available under aCC-BY 4.0 International license.

Gzms in intestinal infection

\section{INTRODUCTION}

A key function of the intestinal epithelium is to serve as a barrier that limits the entry of microbial pathogens into the body. To protect the intestinal epithelium from such pathogens, mammals have developed sophisticated, multi-layered protective mechanisms. These include a range of innate immune defense factors produced by the intestinal epithelial cells, including mucus and antimicrobial peptides. Invasion of epithelial cells by bacterial pathogens triggers the production of proinflammatory cytokines that recruit immune cells to the site of infection. While the early steps of epithelial innate immune defense are well-characterized, the complex interplay between the different immune cells recruited to infected mucosa remain poorly understood. For example, Salmonella enterica serovar Typhimurium (hereafter referred to as Salmonella) infection of the mammalian epithelium induces activation of several types of cytotoxic lymphocytes, including natural killer cells, үठ T cells, innate lymphoid cells, mucosal-associated invariant T (MAIT) cells, yet the relative contributions of each cell type are unclear (Davies et al., 2004; Godinez et al., 2008; Klose et al., 2013; Kurioka et al., 2015; Li et al., 2012). Crucially, the role played by the cytotoxic activity of these various immune cells in controlling bacterial infection is unclear.

Cytotoxic lymphocytes kill target cells by the concerted actions of the serine proteases Granzymes (Gzm) and the pore-forming molecule Perforin, released from secretory granules at the site of contact with the target cell. Perforin mediates pore formation in the target cell membrane allowing for intracellular delivery of Gzms, where Gzms cleave critical intracellular substrates causing cell death. The human genome encodes $5 \mathrm{Gzms}(\mathrm{A}, \mathrm{B}, \mathrm{H}, \mathrm{K}$ and $\mathrm{M})$, whereas the mouse genome encodes $10 \mathrm{Gzms}$ (Kaiserman et al., 2006). Granzyme A (GzmA) and B (GzmB) are the most widely studied Gzms, as they are most highly expressed in cytotoxic lymphocytes, and they are classically implicated as the effectors of granule exocytosis-mediated target cell death. GzmB induces target cell apoptosis mainly by cleaving and activating Caspase- 3 directly or by activating mitochondrial intrinsic apoptosis pathway (Martínez-Lostao et al., 2015). In contrast, GzmA can activate caspaseindependent cell death pathways, but is much less potent than GzmB. Evidence from several independent studies indicate that the key role of GzmA is to drive inflammatory responses (van Daalen et al., 2020). Loss of Perforin (Pfn) in mice abolishes granule mediated target cell death, therefore Pfn is considered essential for granzyme-driven apoptosis. However, GzmA or GzmB single knockout (KO) mice do not recapitulate the loss of cytotoxic lymphocyte activity seen in Pfn $\mathrm{KO}$ animals, indicating some level of redundancy between different Gzms (Voskoboinik et al., 2015). Importantly, multiple studies have found that the individual loss of either GzmA or GzmB has no effect on the immune response to multiple bacterial and viral infections (Arias et al., 2017). Recent evidence suggests that both GzmA and GzmB have significant non-cytotoxic functions that involve cleavage of extracellular and intracellular proteins to promote wound healing, cytokine activation, 
bioRxiv preprint doi: https://doi.org/10.1101/2021.11.07.467595; this version posted November 23, 2021. The copyright holder for this preprint (which was not certified by peer review) is the author/funder, who has granted bioRxiv a license to display the preprint in perpetuity. It is made available under aCC-BY 4.0 International license.

Gzms in intestinal infection

inflammatory responses, and extracellular matrix remodelling (Garzón-Tituaña et al., 2021; Jong et al., 2021; Turner et al., 2019; van Daalen et al., 2020).

One subset of $\mathrm{T}$ lymphocytes that constitutively express GzmA and GzmB are intestinal intraepithelial T lymphocytes (IEL) (Brenes et al., 2021; Shires et al., 2001). IEL are a heterogenous population of $T$ cells that occupy the intracellular space between intestinal epithelial cells. IEL are classified into two main subpopulations based on ontogeny and surface receptor expression. Induced IEL consist of conventional TCRaß CD8a $\beta$ T cells while natural IEL, characterized by the

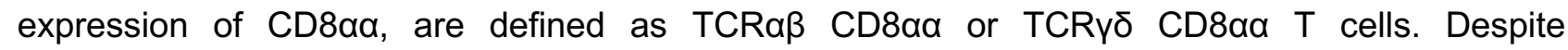
developmental differences, both types of IEL are characterized by an activated phenotype that includes very high expression of GzmA and B, and lower expression of GzmC and GzmK (Brenes et al., 2021). Based on the tissue location and cytotoxic potential of IEL, they have been postulated to play a key role in defending against intestinal infection. One subtype, TCRYס IEL, have been implicated in the defense against oral S. Typhimurium infection ( $\mathrm{Li}$ et al., 2012) and prevent transmigration of bacteria and parasites from the gut by maintaining intestinal barrier integrity (Dalton et al., 2006; Edelblum et al., 2015). Changes in yठ IEL movement have been observed following infection with Salmonella and Toxoplasma gondii (Edelblum et al., 2015; Hoytema van Konijnenburg et al., 2017). IEL also protect against the intracellular protozoan parasite Eimeria vermiformis (Roberts et al., 1996). Taken together, the available data are consistent with IEL being the first immune responders to enteric pathogens. However, the exact mechanism by which IEL protect against foodborne pathogens has remained opaque, and it is currently unknown whether the IEL protective functions are mediated by Gzms.

Here we address a fundamental question: Are Granzymes pivotal for protection against foodborne intracellular bacterial pathogens such as Salmonella spp? Previous studies using KO mice did not find a role for Perforin and GzmB in Salmonella pathogenesis (Lee et al., 2012), but these experiments involved intravenous infections rather than a physiologically relevant Salmonella infection route. Our experiments reveal that the route of infection is important, and that GzmA and GzmB act together to defend the small intestinal epithelium against infection. We show that the majority of GzmA and GzmB in the gut is expressed by IELs, and our data suggest that IEL are responsible for the protective effects of GzmA/B. Surprisingly, we discovered that the intestinal activities of Gzms are Pfn-independent, and that while GzmA has antibacterial functions, GzmB promotes bacterial infection. Our findings reveal novel effector functions of Gzms in tissue-specific control of pathogens, and explain how IEL contribute to intestinal protection. 
Gzms in intestinal infection

\section{RESULTS}

\section{Route and site of infection dictate protective role of Granzymes}

We first tested whether the route of infection dictates the contribution of Gzms to protection against infection. We infected GzmA/GzmB double knockout (GzmA/B dKO) mice with Salmonella strain SL1344, either orally or intravenously. Interestingly, deficiency of GzmA/B made mice significantly more susceptible to oral SL1344 challenge, the natural route of infection. GzmA/B dKO displayed higher weight loss and higher bacterial loads in their mesenteric lymph nodes (mLNs), spleen, and liver (Figure 1A-B). Conversely, absence of GzmA/B did not lead to increased susceptibility towards intravenous infection, quantified in terms of bacterial burden and weight loss (Figure 1C-D). Thus, GzmA and B contribute to protection against oral, but not systemic infection, with this gram-negative intracellular pathogen.

Salmonella mainly enters the gut by actively invading epithelial cells (IEC), or by uptake by M cells or phagocytic sampling of the intestinal lumen. Active IEC invasion, but not the other two routes of entry, requires Salmonella type III secretion system 1 (TTSS-1), which is encoded by Salmonella pathogenicity island 1 (SPI1). To test whether epithelial invasion is necessary to activate the protective effects of Gzms, we used a $\Delta$ SPI1 strain of Salmonella that can still infect mice through phagocytes. We found that no significant difference in the susceptibility of WT and GzmA/B dKO mice to the $\triangle$ SPI1 mutant (Figure 1E-F). The levels of infection seen were low, but dKO mice also had low bacterial burdens.

Next, we tested if the site of infection along the intestine was important for Gzm effector function. We therefore used the streptomycin model of Salmonella infection (Barthel et al., 2003). In this model, the antibiotic streptomycin is given $24 \mathrm{~h}$ before the oral gavage with Salmonella. Streptomycin considerably reduces the commensal bacterial load, and is thought to create a niche in the intestine to allow Salmonella to expand in the cecal lumen, leading to increased infection. Importantly, higher levels of infection were seen mainly in the cecum and colon, with low levels in the small intestine, as opposed to infection without streptomycin as in our previous experiments, where the infection is restricted mainly to the ileum in the small intestine. Interestingly, when we pretreated GzmA/B dKO and WT mice with Streptomycin before Salmonella infection, we found that the bacterial burden was the same in both WT and dKO mice (Figure 1G-H). In summary, these data indicate that GzmA/B specifically protect small intestinal epithelial cells from Salmonella infection, showing that the route and site of infection are important factors in the immune response to murine pathogenesis. 
Gzms in intestinal infection

A

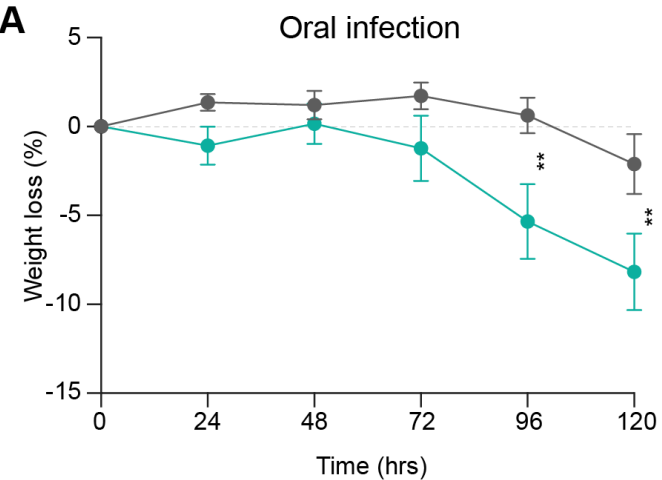

C

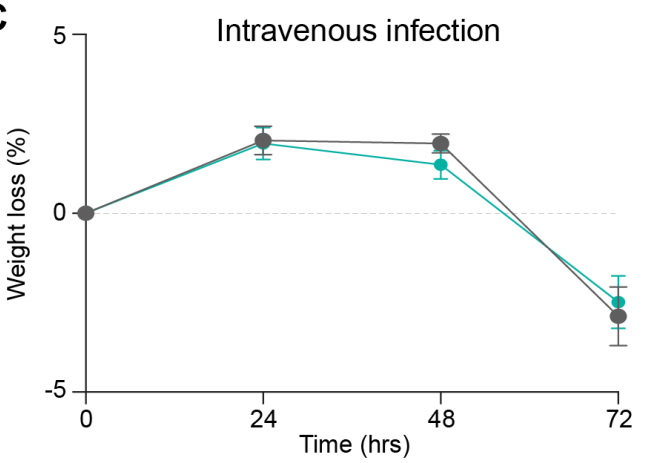

$\mathbf{E}$

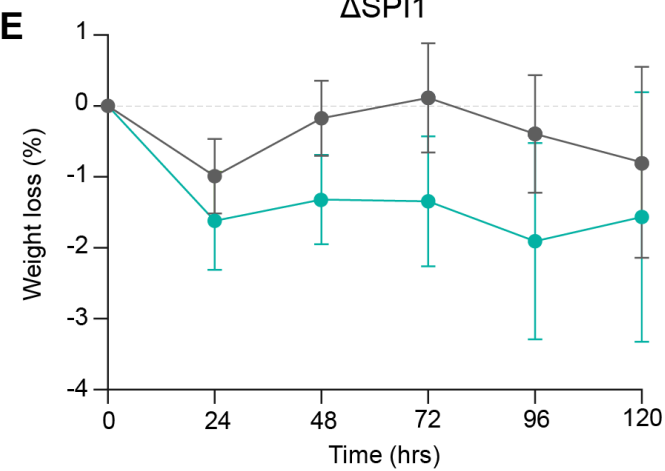

G

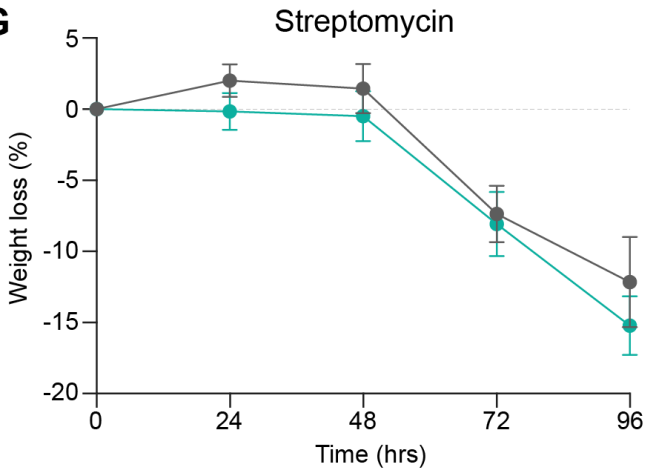

B

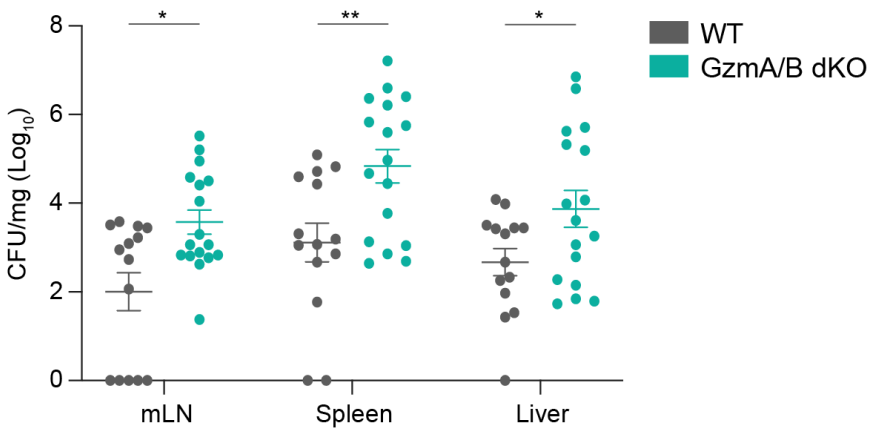

D

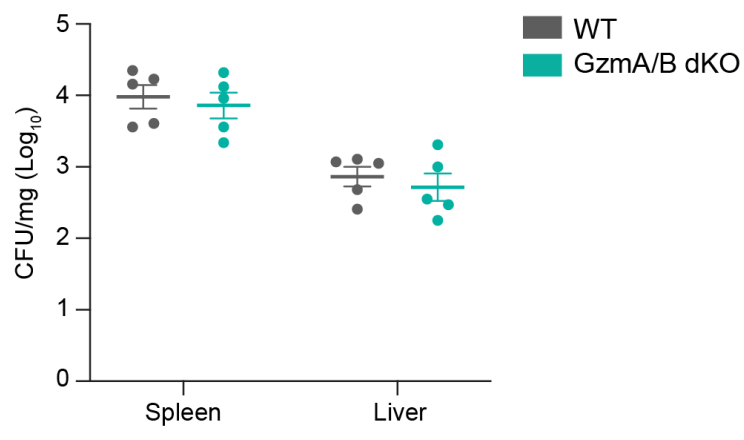

$\mathbf{F}$

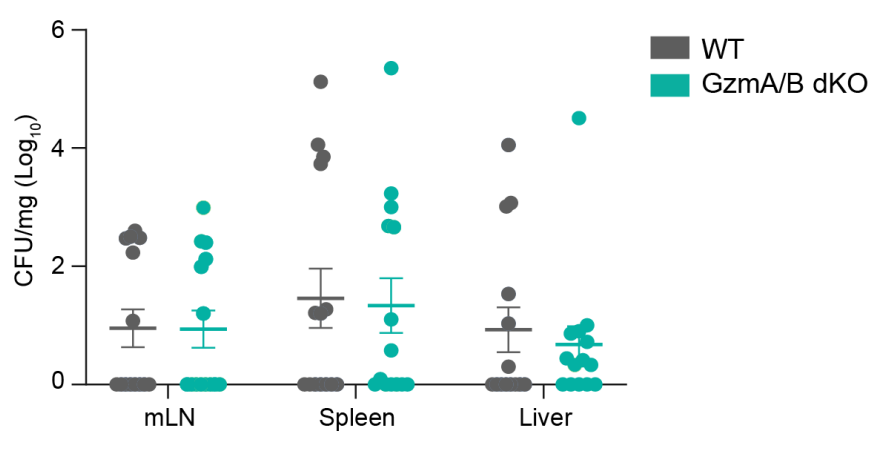

H

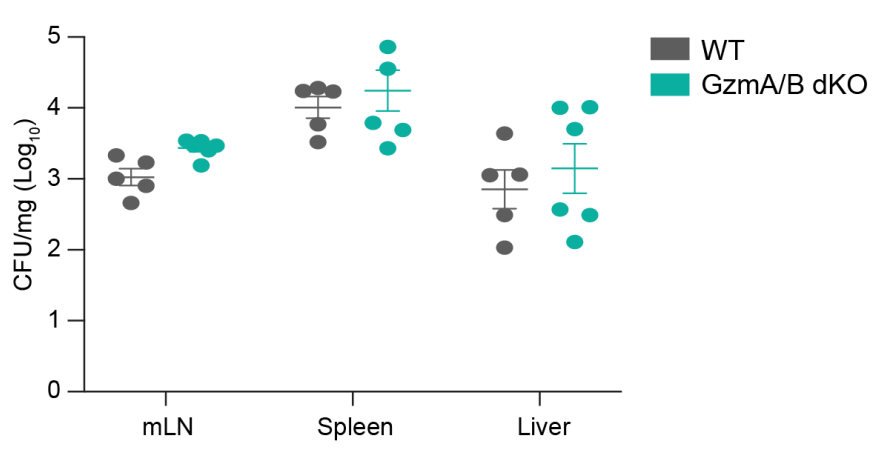

Figure 1. Granzymes are important for protection against intestinal infection

A-B. WT ( $n=14)$ and GzmA/B dKO ( $n=17)$ mice were infected with SL1344-GFP by oral gavage and culled 5 days post infection (dpi). Weight loss (A) and CFU/mg in $\mathrm{mLN}$, spleen and liver at the time of sacrifice (B) are shown. Data were pooled from 3 independent experiments. C-D. WT and GzmA/B dKO mice were infected i.v. with SL1344-GFP and culled 3dpi. Weight loss (C) and CFU/mg in spleen, liver at the time of sacrifice (D) are shown ( $n=5 / g r o u p)$. E-F. WT and GzmA/B dKO mice were gavaged orally with $\triangle$ SPI1-SL1334 and culled 5dpi. Weight loss (E) and CFU/mg in $\mathrm{mLN}$, spleen and liver are shown $(F)$. Data were pooled from 2 independent experiments ( $n=14 /$ group). G-H. Salmonella oral infection of WT $(n=5)$ and $\mathrm{GzmA} / \mathrm{B}$ dKO $(\mathrm{n}=6)$ using the streptomycin model. Mice were given streptomycin in the drinking water and 
bioRxiv preprint doi: https://doi.org/10.1101/2021.11.07.467595; this version posted November 23, 2021. The copyright holder for this preprint (which was not certified by peer review) is the author/funder, who has granted bioRxiv a license to display the preprint in perpetuity. It is made available under aCC-BY 4.0 International license.

Gzms in intestinal infection

gavaged 24h later with $10^{7}$ SL1344-GFP. Weight loss (G) and CFU/mg in $\mathrm{mLN}$, spleen and liver at 4dpi (H) are shown. All data are presented as mean \pm SEM.

\section{IEL-derived GzmA/B contribute to intestinal protection against infection}

Since Gzms are mainly required in the small intestine and not to combat systemic infection, we sought to determine the location and identity of GzmA/B expressing cells. Flow cytometric analyses of spleen, $\mathrm{mLNs}$, and small intestinal (SI) epithelial and lamina propria (LP) layers showed that only SI epithelium harbored a large population of GzmA/B expressing cells before and after oral infection (Figure 2A). The finding was confirmed by imaging GzmA and GzmB in the gut (Figure 2B and Supplementary Figure 1). In the epithelial compartment, around $90 \%$ of GzmA/B+ cells are T cells, either TCRaß+ or TCRy $\delta+$, while in the LP, the majority of GzmA/B+ cells are CD8a+ (Figure 2C). We conclude that IEL are the major expressers of both GzmA and GzmB in the SI.

That IEL express Gzm constitutively at steady-state has been known for a long time, however the function of IEL-expressed Gzms is unknown. More than $80 \%$ of IEL express GzmA and GzmB, and previous proteomic analyses showed that IEL subsets express up to 20 million molecules of GzmA and $\sim 5$ million molecules of GzmB per cell (Brenes et al., 2021). Since IEL express such high levels constitutively, we first determined whether loss of Gzms affected IEL homeostasis in any way. IEL numbers were comparable to WT in Gzm sKO and dKO mice (Supplementary Figure 2A). No compensatory expression of GzmA in GzmB sKO, or GzmB in GzmA sKO IEL was seen (Supplementary Figure 2B), as previously found in other cell types (Pardo et al., 2008). We also assessed the surface phenotype of IEL. Known tissue retention markers, such as CD69 and CD103, as well as recently described inhibitory receptors, such as CD96 and CD160, were expressed at similar levels on IEL in the absence of Gzms (Supplementary Figure 2C). IEL are highly motile cells that exhibit patrolling immunosurveillance of the gut epithelium, both in vivo and in vitro (Edelblum et al., 2012; Hoytema van Konijnenburg et al., 2017; Hu et al., 2018). As Gzms can cleave ECM proteins, it was possible that IEL require Gzms to move efficiently within the epithelial layer. To test this, we utilized co-cultures of IEL with 3D intestinal epithelial organoids. The movement of WT and dKO IEL was tracked within the epithelial layer of co-cultures. IEL were indeed motile, with a velocity of $\sim 30 \mathrm{~nm} . \mathrm{s}^{-1}$, and both WT and dKO IEL moved at a similar speed (Supplementary Figure 2D). Thus, IEL are the major cell type expressing GzmA and GzmB constitutively in the mouse, yet GzmA/B dKO IEL appear to be functionally and phenotypically normal in uninfected mice. 
Gzms in intestinal infection

A
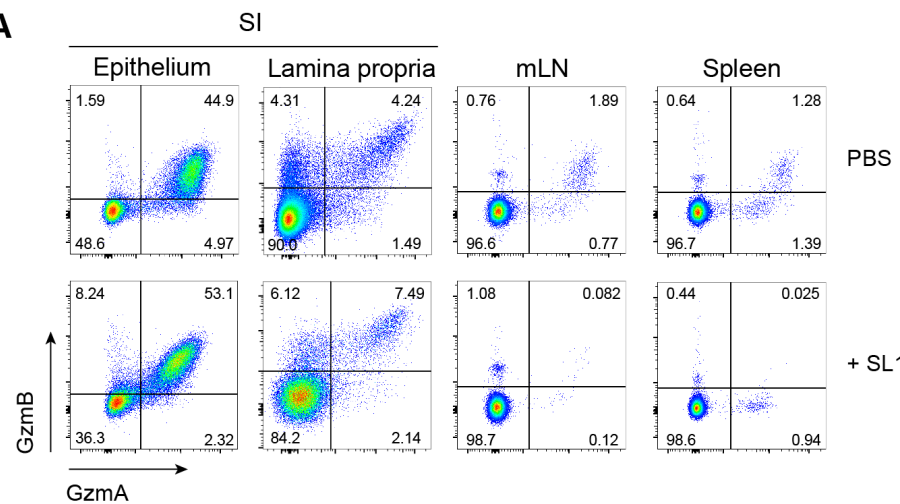

+ SL1334

B
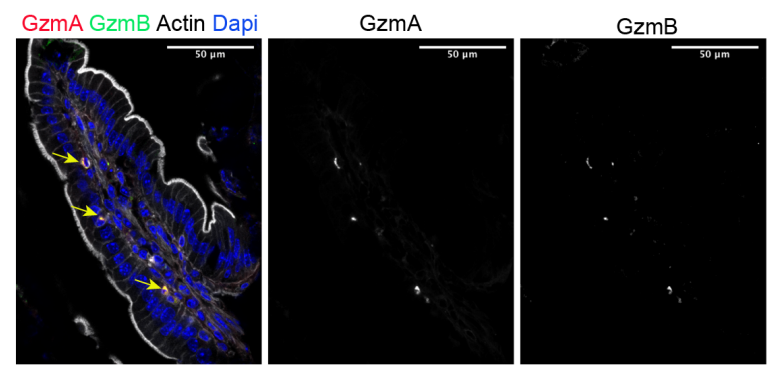

C
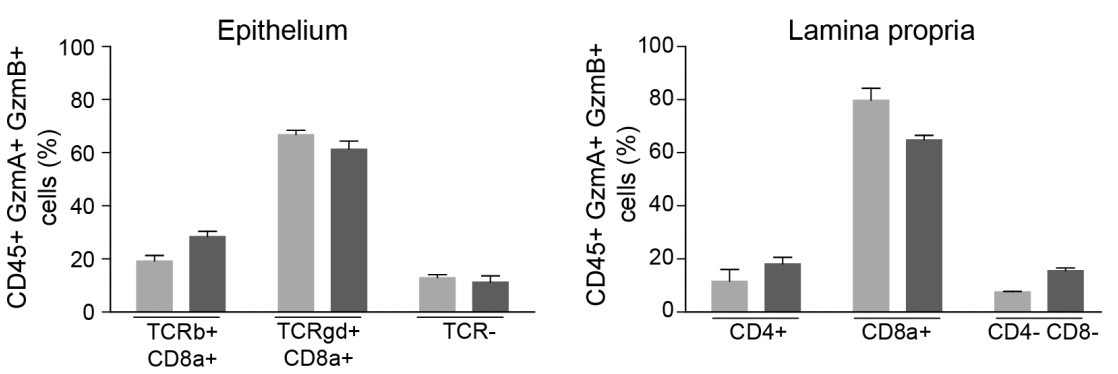

D

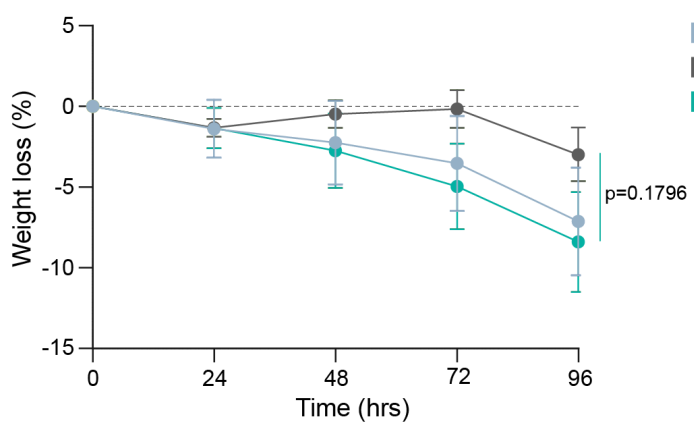

E
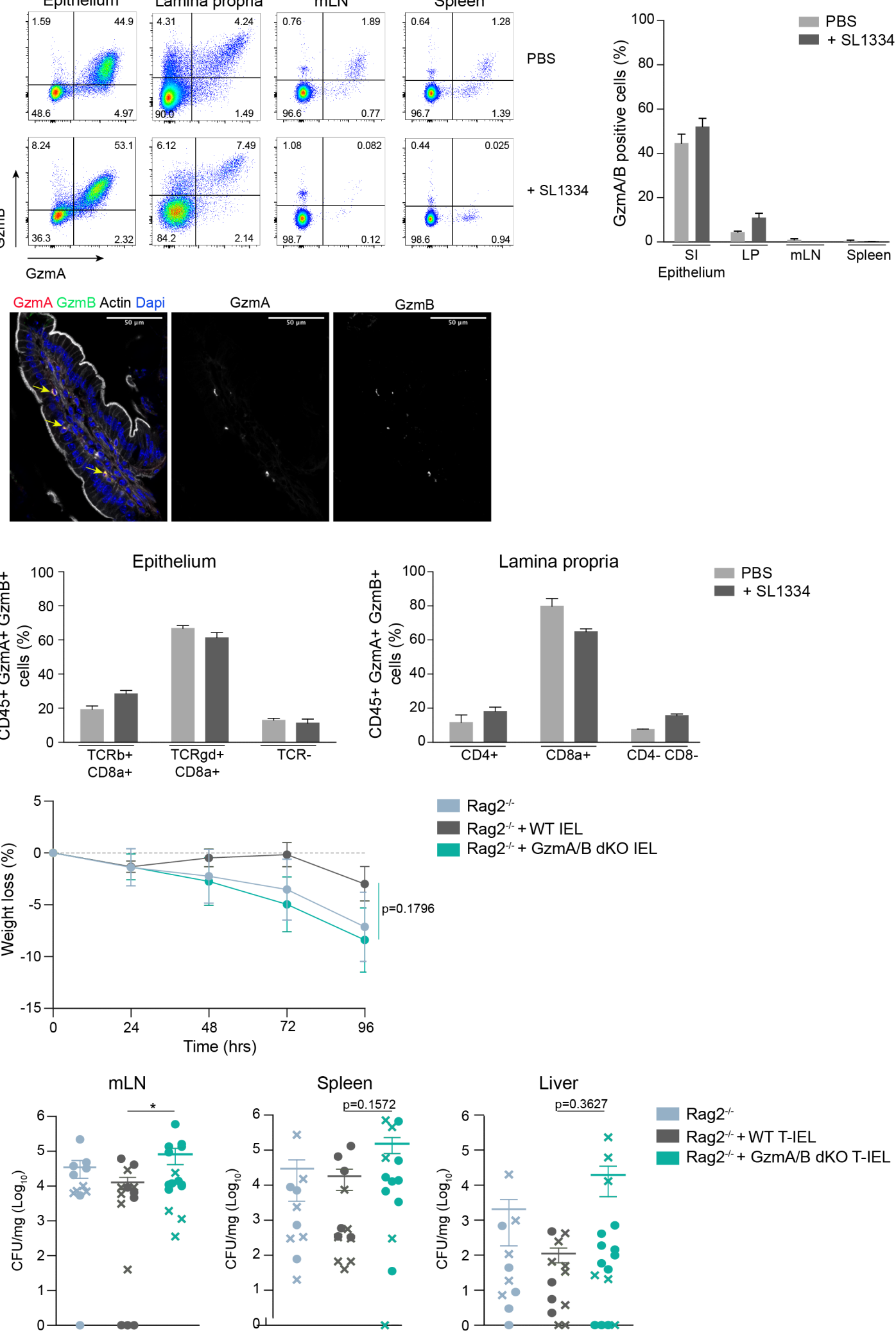

Figure 2. IEL are the major drivers of Gzm-dependent intestinal protection

A. Representative flow cytometry dot plots of GzmA and GzmB expression in the small intestine epithelium, lamina propria, $\mathrm{mLN}$ and spleen of naïve and orally infected WT mice (left). Bar graphs (right) display the percentage of GzmA/B+ cells in the indicated organs $(n=5)$. B. Immunofluorescent micrographs showing cells expressing GzmA (middle panel and red on left panel) and GzmB (right panel, and green on left panel) in the epithelial layer of a jejunal villus. Sections were 
bioRxiv preprint doi: https://doi.org/10.1101/2021.11.07.467595; this version posted November 23, 2021. The copyright holder for this preprint (which was not certified by peer review) is the author/funder, who has granted bioRxiv a license to display the preprint in perpetuity. It is made available under aCC-BY 4.0 International license.

Gzms in intestinal infection

counterstained with phalloidin to show actin (white on left panel) and DAPI to show nuclei (blue on left panel). Scale

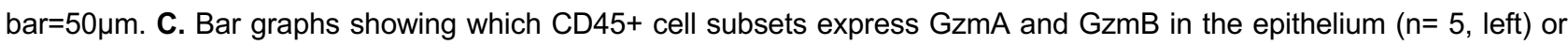
lamina propria $(n=6$, right) in the small intestines of naïve and orally infected WT mice. D-E. Rag2- mice adoptively transferred with WT $(n=12)$ or GzmA/B dKO IEL $(n=15)$, were orally gavaged with $1.5 \times 10^{8}$ SL1344-GFP. Data were pooled from two independent experiments where infected mice were either culled 4dpi (circles) or $5 \mathrm{dpi}$ (crosses), dependent on the severity. Weight loss (D) and CFU/mg (E) in mLN (left), spleen (middle) and liver (right) are shown. All data are presented as mean \pm SEM.

To address whether IEL were required for the protective effects of Gzms against Salmonella infection, we adoptively transferred WT or GzmA/B dKO IEL to RAG2 KO mice. To improve the transfer efficiency and to enhance survival, we first cultured cells for $24 \mathrm{~h}$ with IL-15 and retinoic acid, as we found that this combination increased the expression of the gut-homing proteins CCR9 and $\alpha 4 \beta 7$ (Supplementary Figure 2E) and increased the efficiency of the transfer (Supplementary Figure 2F). IEL from either genotype repopulated the intestinal epithelial compartment of RAG2 KO mice equally efficiently (Supplementary Figure 2G). After a 4-week period that allowed the adoptively transferred IEL to sufficiently repopulate the gut, the mice were infected orally with Salmonella. Despite large variability in the experiment, we found that overall, RAG2 KO mice reconstituted with GzmA/B dKO IEL had a higher infection burden than RAG2 KO with WT IEL (Figure 2D and E). dKO IEL reconstituted mice also lost more weight than WT reconstituted RAG2 KO, similar to RAG2 KO mice. Moreover, 3 RAG2 KO that did not receive any IEL had to be culled early due to the severity to the infection, even though other Gzm expressing innate cells had expanded to fill the epithelial niche in RAG2 KO mice. Thus, IEL are required and are sufficient to mediate the protective effects of Gzms against intestinal infection.

\section{GzmA and GzmB have opposing roles in protection against intestinal infection}

We recently showed that the cytotoxic activity of IL-15 stimulated IEL is dependent on the expression of GzmA/B (James et al., 2021). Because the cytotoxic functions of Gzms are generally Pfndependent (Jaime-Sánchez et al., 2018; Pardo et al., 2004), we asked whether Pfn was required for GzmA/B mediated protection against intestinal infection. Surprisingly, we found that Pfn KO mice were not more susceptible to oral Salmonella infection than WT mice (Figure 3A-B). These data indicate that IEL do not use Pfn-mediated killing of infected cells as a mechanism to control Salmonella infection.

Our findings prompted us to test the relative importance of the individual Gzms, as GzmA and GzmB are proteases with very different specificities (Voskoboinik et al., 2015). Therefore, we orally infected both $\mathrm{GzmA}^{-/-}(\mathrm{GzmA} \mathrm{sKO})$ and $\mathrm{GzmB}^{-/-}$(GzmB sKO) mice with Salmonella to test the relative contributions of each Gzm. Salmonella infection of GzmA sKO mice caused similar symptoms as 
seen in dKO mice, which included greater weight loss and higher bacterial burdens than WT mice, albeit the difference in bacterial burden was less pronounced compared to that in dKO mice (Figure 3C-D). Surprisingly, GzmB sKO mice were significantly protected against Salmonella infection, with no systemic bacteria found in many of the mice after 5 days of infection (Figure 3E-F).
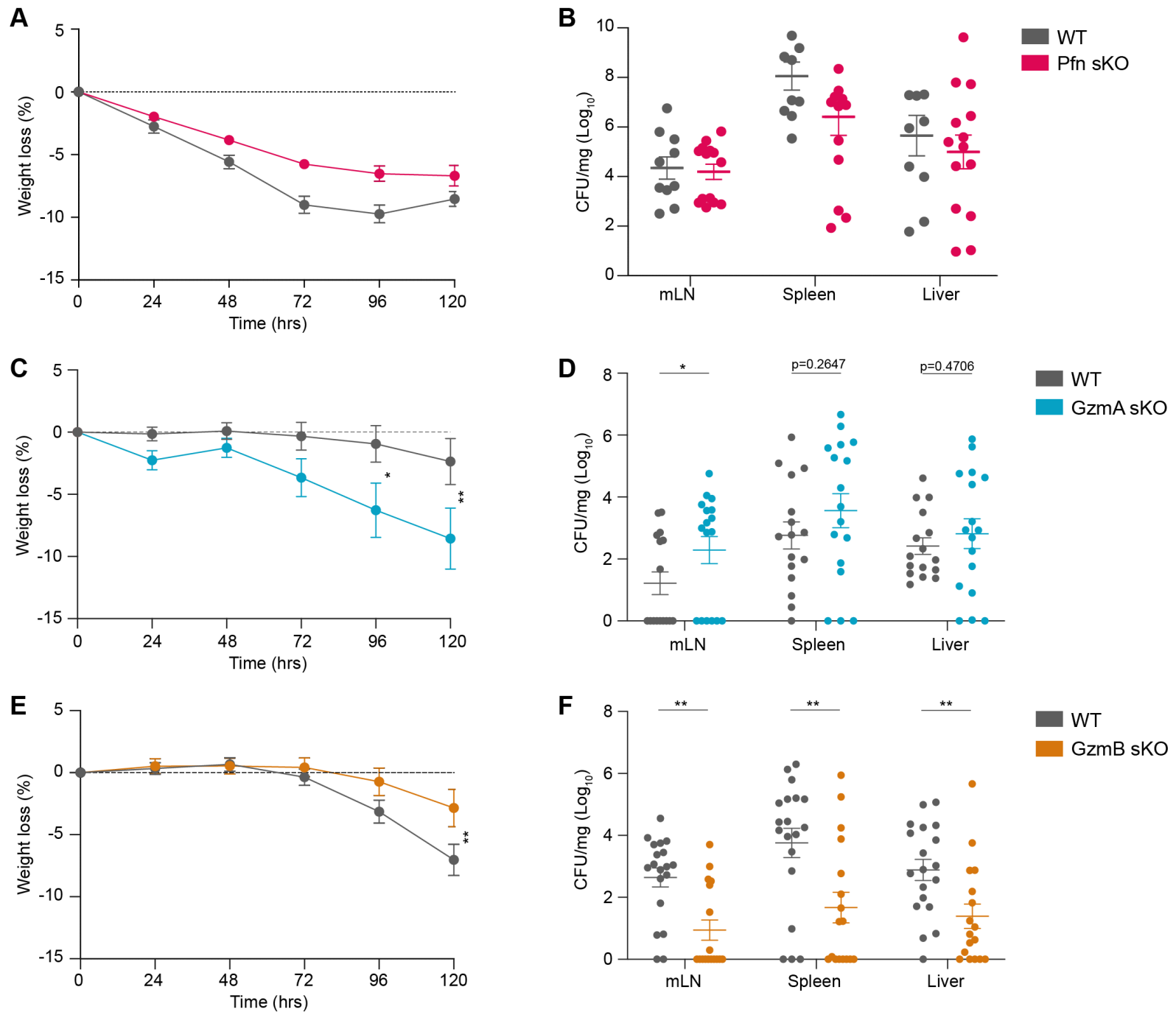

Figure 3. Divergent roles of Perforin, GzmA and GzmB in intestinal infection

A-B. WT ( $n=10)$ and Pfn KO ( $n=14)$ mice were orally gavaged with 1.5 $\times 10^{8}$ SL1344-GFP and culled 5dpi. Weight loss (A) and CFU/mg in MLN, spleen and liver at the time of sacrifice (B) are shown. C-D. WT ( $n=19)$ and GzmA sKO $(n=18)$ mice were orally gavaged with $1.5 \times 10^{8} \mathrm{SL} 1344-\mathrm{GFP}$ and culled $5 \mathrm{dpi}$. Weight loss (C) and CFU/mg in $\mathrm{mLN}$, spleen and liver (D) are shown. Data were pooled from 2 independent experiments. E-F. WT $(n=19)$ and GzmB sKO $(n=17)$ mice were oral

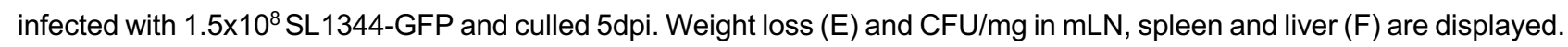
Data were pooled from 2 independent experiments. All data are presented as mean \pm SEM.

As well as inducing cell death, both GzmA and GzmB can also regulate inflammatory cytokine production, with GzmA in particular activating key innate defense cytokines such as IL-1 $\beta$, TNF or IL-6 (Garzón-Tituaña et al., 2021; Hildebrand et al., 2014; Metkar et al., 2008; Omoto et al., 2010; 
bioRxiv preprint doi: https://doi.org/10.1101/2021.11.07.467595; this version posted November 23, 2021. The copyright holder for this preprint (which was not certified by peer review) is the author/funder, who has granted bioRxiv a license to display the preprint in perpetuity. It is made available under aCC-BY 4.0 International license.

Gzms in intestinal infection

Santiago et al., 2020). Therefore the levels of cytokines in the plasma of orally infected WT, dKO, and SKO mice were determined at the time of the sacrifice. We found that the levels of cytokines and chemokines in the dKO mice were mostly increased compared to WT mice, especially IL-18, but this increased cytokine production was not seen in the GzmA sKO mice (Supp Figure 3A and 3B). In contrast, the GzmB sKO mice showed markedly reduced production of all cytokines and chemokines tested after infection (Supplementary Figure 3C). We conclude that the cytokine levels in the plasma of infected mice correlate with the bacterial burden rather than with the loss of Gzm.

As the differences seen in the systemic cytokine responses did not correlate with the functions of Gzms in inducing inflammatory cytokines, we next evaluated the functions of gzms in cleaving extracellular proteins. Gzms can cleave extracellular matrix proteins and epithelial cell junction proteins (Buzza et al., 2005; Hendel et al., 2010; Prakash et al., 2014), so could potentially increase bacterial translocation across a leaky barrier. Since previous studies have shown that intestinal permeability is not increased in GzmA sKO mice (Santiago et al., 2020), we only tested intestinal permeability in GzmB sKO mice. We did not find any difference compared to WT mice, either before or after infection (Supplementary Figure 4).

In summary, these data indicate that GzmA and GzmB play opposing roles in intestinal protection, with GzmA protecting against a foodborne pathogen, and GzmB decreasing resistance to Salmonella infection, and both Gzms function in a Pfn-independent manner.

IEL derived Granzymes have differential functions in the response to epithelial Salmonella infection

To understand how IEL and Gzms were protecting intestinal epithelial cells against infection, we utilized a cell culture infection system. Purified IEL were incubated with a luciferase-expressing strain of Salmonella (SL1344-lux), then the SL1344-lux/IEL mix was used to infect the murine small intestinal epithelial cell line, MODE-K. After infecting for 1 hour, any extracellular Salmonella was killed using gentamycin, and intracellular growth was assessed at various time points by measuring luciferase activity. Pre-incubation of Salmonella with IEL reduced the ability of the bacteria to infect epithelial cells, but this did not depend on IEL expression of Gzms (Figure 4A). Cell-free growth of Salmonella was not affected by the presence of IEL (Figure 4B), suggesting that IEL do not impact upon the replication ability of Salmonella. 
Gzms in intestinal infection

A

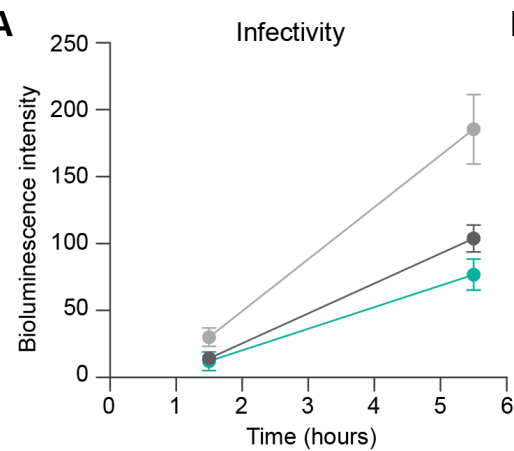

C

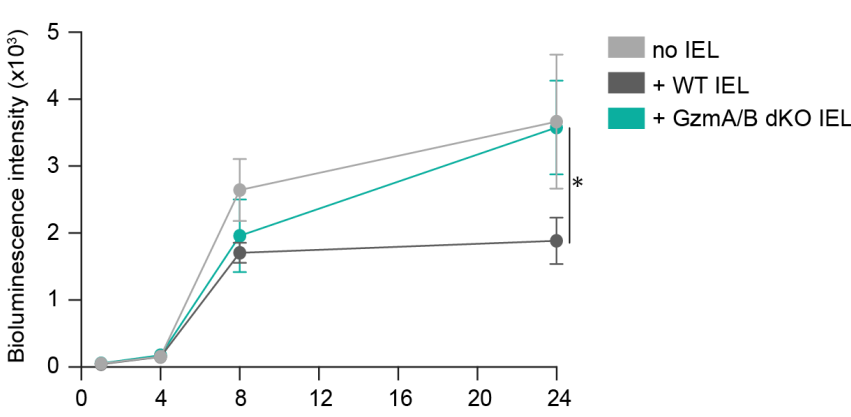

D

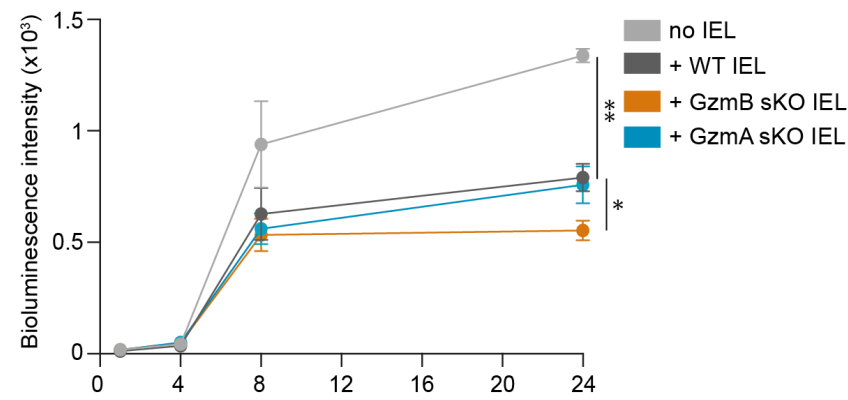

B

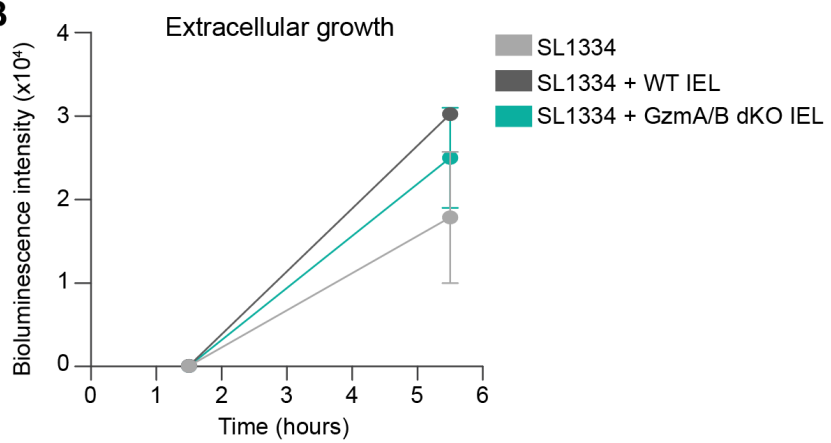

E

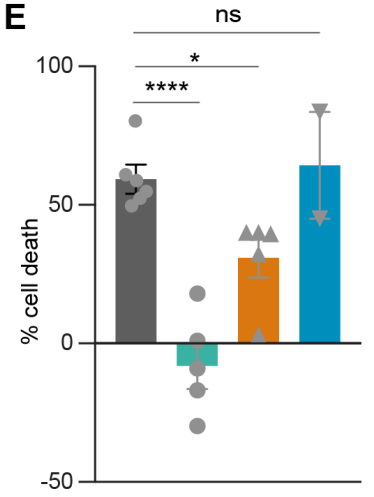

+ WT IEL

+ GzmA/B dKO IEL

+ GzmB sKO IEL

+ GzmA sKO IEL

Figure 4. Effects of IEL derived GzmA and GzmB on Salmonella infectivity and growth

A-C. Effect of WT and GzmA/B KO IEL on Salmonella infectivity (A), extracellular growth (B) and intracellular growth (C) $(n=3)$. A. MODE-K cells were infected with SL1334-lux in presence of IEL for $1 \mathrm{~h}$, then treated with gentamycin to kill any extracellular bacteria $(\mathrm{t}=1 \mathrm{~h} 30)$. Bioluminescence intensity was measured at $1 \mathrm{~h} 30$ and $5 \mathrm{~h} 30$ time points. B. SL1334-lux and IEL were cultured together, and bioluminescence intensity was measured after $1 \mathrm{~h} 30$ and $5 \mathrm{~h} 30$. C. MODE-K cells were infected with SL1334-lux for $1 \mathrm{~h}$ and then incubated with WT or GzmA/B dKO IEL. Bioluminescence intensity was measured when IEL were added, then after 4h, 8h and 24h. D. Infected MODE-K cells were incubated with WT or Gzm sKO IEL, similar to $(C)(n=3)$. E. Infected MODE-K cells were stained with Crystal violet $24 \mathrm{~h}$ after incubation with WT (n=6), GzmA/B dKO $(n=5), G z m B$ sKO $(n=5), G z m A$ sKO $(n=2)$, pooled from 4 independent experiments. The percentage cell death relative to infected MODE-K cells without IEL was calculated and plotted. One-way ANOVA with Dunnett's multiple comparisons was used to calculate significance. All data are presented as mean \pm SEM.

We then determined whether IEL inhibited the growth of Salmonella within infected epithelial cells. MODE-K cells were first infected with SL1334-Iux for $1 \mathrm{~h}$, then incubated with purified IEL. Here we found that after $24 \mathrm{~h}$ incubation of infected IEC with WT IEL, there was a marked reduction in the intracellular growth of Salmonella. Strikingly, no reduction in the intracellular growth of SL1344-lux was seen in the co-culture of MODE-K with GzmA/B dKO IEL (Figure 4C). GzmA sKO IEL and 
bioRxiv preprint doi: https://doi.org/10.1101/2021.11.07.467595; this version posted November 23, 2021. The copyright holder for this preprint (which was not certified by peer review) is the author/funder, who has granted bioRxiv a license to display the preprint in perpetuity. It is made available under aCC-BY 4.0 International license.

Gzms in intestinal infection

GzmB sKO IEL were at least as good as WT IEL in blocking the intracellular growth of SL1344-lux in MODE-K cells, with GzmB sKO IEL appearing even more efficient than WT IEL (Figure 4D). These data recapitulate our in vivo findings in Gzm sKO mice infected orally with Salmonella. Finally, we investigated whether WT IEL were killing the infected MODE-K cells, by staining living cells with Crystal Violet (Figure 4E). We found that while incubation with WT IEL reduced numbers of viable MODE-K cells, GzmA/B dKO IEL did not affect the viability of the infected MODE-K cells. GzmA sKO IEL killed infected MODE-K cells as efficiently as WT, and GzmB sKO were slightly less efficient. Our data support the notion that GzmA, possibly with some contribution from GzmB, is required for IEL to effectively protect small intestinal epithelial cells from Salmonella infection, both by blocking infection, and by killing infected IEC. In contrast, GzmB limits the ability of IEL to control Salmonella infection, potentially in a cell death independent manner.

\section{DISCUSSION}

In this study, we explored the relative contributions of GzmA, GzmB and Perforin, in providing protection against infection at the intestinal barrier. We show that IEL are the major cell type constitutively expressing GzmA and GzmB. To our knowledge this is the first study showing a direct protective effect of IEL-derived Granzymes in intestinal infection. Interestingly, this protective effect was independent of Perforin, and was more nuanced than anticipated, as it appears to depend on the concerted activities of GzmA and GzmB. One possible explanation for how this protection is mediated in the absence of Pfn, is that GzmA induces or enhances pro-inflammatory cytokine production from epithelial cells, particularly IL-1 $\beta$ and IL-18, either directly or indirectly through inflammasome activation (Hildebrand et al., 2014; Metkar et al., 2008). In the absence of GzmA, GzmB may also contribute to IL-18 production in a Caspase-1 independent manner (Akeda et al., 2014). It is also possible that Gzms contribute to the expulsion of infected epithelial cells from the gut wall (Rauch et al., 2017; Sellin et al., 2014), as a recent study showed that LPS-induced epithelial cell shedding required Perforin independent activities of GzmA and GzmB (Hu et al., 2021). However, we found that GzmB KO mice were protected from Salmonella infection, making it unlikely that there is reduced expulsion of infected epithelial cells in GzmB KO mice.

In this context, we make the surprising finding that presence of GzmB increased susceptibility to Salmonella infection, rather than providing protection. This seemingly counter-intuitive finding could be explained by recent evidence showing that apoptosis of intestinal epithelial cells supports the growth of Salmonella, by providing catabolic nutrients (Anderson et al., 2021). Thus, the induction of apoptosis of infected epithelial cells by GzmB could support the growth of Salmonella. An alternative explanation might be the increased activation of the antibacterial cellular mechanisms due to a reduction in regulatory $T$ cell (Treg) function in the absence of GzmB as previously found in 
Gzms in intestinal infection

cancer models. Indeed, GzmB KO mice are more resistant to some tumors as they show increase anti-tumoral NK and cytotoxic T cell function due to reduced Treg activity (Cao et al., 2007). However, we find that in vitro in the absence of Treg, GzmB KO IEL were still more efficient than WT IEL in reducing levels of Salmonella growth, indicating that the observed effects are Tregindependent. It is worth noting that despite the increased resistance to infection seen in GzmB KO, loss of GzmA was dominant over the loss of GzmB, and the infection progression in GzmA/B dKO mice phenocopied GzmA KO mice. This result agrees with previous findings in in vivo tumor models where the anti-tumoral advantage observed in mice that do not express GzmB is lost when, additionally, GzmA is absent in GzmA/B dKO (Cao et al., 2007), suggesting that the increased ability of GzmB deficient IELs to clear Salmonella infection is mediated by GzmA.

The route that pathogens use to infect their hosts has a profound impact on the evolution of the host's immune adaptations to them. Evolution of Gzms in particular, show evidence of speciesspecific adaptation to selection pressures enforced by pathogens and the environment (Kaiserman et al., 2006). Gzms play multi-faceted roles that involve novel activities that are still being assigned, such as the function of human GzmA in driving pyroptosis by cleaving Gasdermin B (Zhou et al., 2020). While it remains to be established exactly how GzmA functions, especially since the activity of this protease is potentially enhanced by $\mathrm{GzmB}$, we have now established that GzmA protects the gut against intestinal infection. Importantly, our work establishes a new paradigm where a Pfnindependent role of GzmA and not classical Pfn/GzmB-driven cell death mediates protection against microbial infection. 
bioRxiv preprint doi: https://doi.org/101101/2021.11.07.467595; this version posted November 23, 2021. The copyright holder for this

Gzms in intestinal infection

\section{Funding and acknowledgements:}

The authors would like to thank the staff of the Biological Resource units, the MRC Genotyping team, the Flow Cytometry and Imaging facilities from the University of Dundee, and the animal care staff and Servicios Científico Técnicos del CIBA (IACS-University of Zaragoza) and Servicio Apoyo Investigación (University of Zaragoza) for invaluable assistance. This work was supported by the Wellcome Trust and Royal Society (Sir Henry Dale Fellowship to MS, 206246/Z/17/Z) and, in part by a Wellcome Trust Senior Investigator award [106914/Z/15/Z] to JCDH, and by ARAID Foundation and grant SAF2017-83120-C2-1-R and PID2020-113963RBI00 from the Ministry of Science and Innovation/ Agencia Estatal de Investigacion and FEDER (Group B29_17R, Aragon Government) to JP. LS was supported by a PhD fellowship (FPI) from the Ministry of Science, Innovation and Universities. MA was supported by a post-doctoral fellowship "Juan de la Cierva-formación" and "Juan de la Cierva-incorporación" from the Ministry of Science, Innovation and Universities. For the purpose of open access, the authors have applied a CC BY public copyright licence to any Author Accepted Manuscript version arising from this submission.

\section{Competing interests}

The authors have declared no competing interests. 
Gzms in intestinal infection

\section{METHODS}

\section{Mice}

$\mathrm{GzmA}^{-/-} \mathrm{GzmB}^{-/}, \mathrm{GzmA}^{-/}, \mathrm{GzmB}^{-/-}$were bred in the University of Dundee and Prf1 ${ }^{-/-}$(Perforin) mice were bred at the University of Zaragoza. GzmA ${ }^{--} \mathrm{GzmB}^{-/}$and $\mathrm{Prf1}^{-/-}$mice were co-housed with control age- and sex-matched C57BL/6J mice at weaning (between 3-4 weeks of age), whereas for experiments with $\mathrm{GzmA}^{-/}$or $\mathrm{GzmB}^{-/}$, wild-type littermate controls were used wherever possible. C57BL/6J and Rag2 ${ }^{-/}$(RAGN12) mice were purchased from Charles Rivers and Taconic, respectively. All mice were bred and maintained with approval by the University of Dundee ethical review committee, under a UK Home Office project license (PD4D8EFEF) in compliance with U.K. Home Office Animals (Scientific Procedures) Act 1986 guidelines, or approval by the University of Zaragoza ethical review committee (PI53/20) designated as Animal Welfare Body (Article 34, Royal Decree 53/2013).

\section{Bacterial strains}

Derivatives of Salmonella enterica serovar Typhimurium strain SL1344 were used: SL1334-GFP, containing a plasmid expressing GFP-Ova (pMW57) under the control of the pagC promoter (obtained from D. McEwan, Dundee with permission from D. Bumann, Basel) (Bumann, 2002); SL1344-Lux was generated by introducing pEM7-lux plasmid (that expresses luxCDABE constitutively under the control of the synthetic promoter PEM7 (Lane et al., 2007)); $\triangle$ SPI1 strain (JVS-00405) was obtained from J. Vogel's lab (Würzburg), and is a $\lambda$-Red knockout of the entire SPI1 island (Sittka et al., 2007).

\section{Infections and CFU determination}

9-12 weeks old female (18g-23g) and male (24g-30g) mice were infected with ampicillin-resistant SL1334-GFP. Bacteria were grown overnight in LB broth supplemented with ampicillin (100 $\mu \mathrm{g} / \mathrm{ml})$ at $37^{\circ} \mathrm{C}$, on a shaker, then subcultured in $\mathrm{LB}+$ ampicillin medium for at least $3 \mathrm{~h}$ before in vivo infection. Bacteria were centrifuged $10 \mathrm{~min}$ at $3750 \mathrm{rpm}$, washed and resuspended in sterile PBS. The OD600 was measured to estimate bacterial density. Serial plating on LB agar supplemented with ampicillin $(100 \mu \mathrm{g} / \mathrm{ml})$ were performed to quantify the infection dose. For oral infection, food was removed at least $3 \mathrm{~h}$ before gavage and mice were infected with $1.5 \times 10^{8}$ bacteria. For intravenous infection, mice were infected with 500 bacteria. For the streptomycin infection model, streptomycin sulphate (Sigma) was added into the drinking water for $24 \mathrm{~h}$ (final concentration of $5 \mathrm{mg} / \mathrm{ml}$ ), $46 \mathrm{~h}$ before oral infection. On the day of infection, food was removed at least $3 \mathrm{~h}$ before gavage. Mice were orally infected with $100 \mu$ l of PBS containing a total of $10^{7}$ bacteria. To determine if epithelial cell invasion is necessary for granzyme action, the $\triangle$ SPI1 strain was used at a concentration of $9 \mathrm{x}$ $10^{9}$ bacteria per mouse. In addition to weight loss monitoring, mice were monitored a minimum of 
bioRxiv preprint doi: https://doi.org/10.1101/2021.11.07.467595; this version posted November 23, 2021. The copyright holder for this preprint (which was not certified by peer review) is the author/funder, who has granted bioRxiv a license to display the preprint in perpetuity. It is made available under aCC-BY 4.0 International license.

Gzms in intestinal infection

twice a day for apparition of clinical signs and a scoring system was used to assess the severity of infection.

For CFU determination, mice were euthanized by a rising concentration of $\mathrm{CO}_{2}$ and death was confirmed by cervical dislocation. $\mathrm{mLNs}$ and spleen were collected, weighed, and transferred into $2 \mathrm{ml}$ Precellys $®$ (Bertin) tubes containing ceramic beads and PBS $+0.05 \%$ Triton X-100 (Sigma). Tissues were homogenized using the Precellys ${ }^{\circledR} 24$ homogenizer (Bertin) for $2 \times 10 \mathrm{~s}$ at $5000 \mathrm{~Hz}$. Livers were weighed and crushed through a $70 \mu \mathrm{m}$ strainer in PBS+ $0.05 \%$ Triton X-100. Supernatants were serial diluted in LB + ampicillin $(100 \mu \mathrm{g} / \mathrm{ml})$ medium and plated on LB + ampicillin plates. Colonies were counted after overnight incubation at $37^{\circ} \mathrm{C}$.

\section{In vivo intestinal permeability assay}

Naïve and infected mice were treated with FITC-dextran dissolved in PBS $(100 \mathrm{mg} / \mathrm{ml})$. Prior to treatment, mice were starved for $4 \mathrm{~h}$. Each mouse received $44 \mathrm{mg}$ of FITC-dextran solution per $100 \mathrm{~g}$ body weight by oral gavage. After $4 \mathrm{~h}$, blood was collected, and the serum was separated. The concentration of FITC-dextran in serum was quantified by spectrophotometry with an excitation of $485 \mathrm{~nm}$ using a CLARIOstar Plus plate reader.

\section{IEL isolation}

IEL were isolated as described in (James et al., 2020). Briefly, small intestines were cut from proximal duodenum to terminal ileum and flushed with $20 \mathrm{ml}$ of cold PBS. Small intestines were longitudinally opened, then transversely cut into $\sim 5 \mathrm{~mm}$ pieces and put into $25 \mathrm{ml}$ of warm RPMI medium (RPMI; 10\% FBS; 1\% glutamine; 1\% penicillin-streptomycin), containing 1mM DTT. Small intestine pieces were agitated on a rotator or bacterial shaker for $40 \mathrm{~min}$ at room temperature, centrifuged, vortexed and passed through a $100 \mu \mathrm{m}$ sieve. Cells were centrifuged in a $36 \% / 67 \%$ Percoll/PBS density gradient at $700 \mathrm{~g}$ for 30 minutes. Total IEL were collected from the interface between $36 \%$ and $67 \%$ Percoll. CD8 $\alpha+$ IEL were purified using the EasySep mouse CD8 $\alpha$ positive selection kit II (STEMCELL Technologies), with small changes from the manufacturer's instructions: Total IEL were resuspended in $250 \mu$ of isolation medium. After incubation with Fc blocker and antibody cocktail mix (at a concentration of $10 \mu \mathrm{l} / \mathrm{ml}$ and $50 \mu \mathrm{l} / \mathrm{ml}$, respectively), $80 \mu \mathrm{l} / \mathrm{ml}$ of dextran beads were added to the cells. Labelled cells were then incubated in the magnet for $5 \mathrm{~min}$ before pouring off the supernatant. The remaining cells were collected and used as CD8 $\alpha+$ IEL. Purity ranged between $75 \%-85 \%$.

\section{LPL isolation}

Small intestines were cut from proximal duodenum to terminal ileum and flushed with $20 \mathrm{ml}$ of cold PBS. Small intestines were longitudinally opened and stored on ice in $10 \mathrm{ml}$ of PBS. Samples were vortexed 3 times for 10 seconds in PBS. Small intestines were then incubated for 30 min, with constant shaking, in "strip buffer" (PBS; $5 \%$ FBS; $1 \mathrm{mM} \mathrm{EDTA}, 1 \mathrm{mM} \mathrm{DTT}$ ), prewarmed at $37^{\circ} \mathrm{C}$. After 
bioRxiv preprint doi: https://doi.org/10.1101/2021.11.07.467595; this version posted November 23, 2021. The copyright holder for this preprint (which was not certified by peer review) is the author/funder, who has granted bioRxiv a license to display the preprint in perpetuity. It is made available under aCC-BY 4.0 International license.

Gzms in intestinal infection

the incubation, tissue was washed in PBS, then incubated for 45 min with constant shaking with "digest buffer" (RPMl; 10\% FBS; 1mg/ml collagenase/dispase (Roche); 20 $\mu \mathrm{g} / \mathrm{ml}$ DNAse 1 (Sigma)). Supernatants containing LPL were then collected by pouring over a $70 \mu \mathrm{m}$ filter into a new tube containing RPMI media supplemented with $10 \%$ FBS.

\section{Adoptive transfer}

6 to 8 weeks old male and female Rag $2^{-/-}$mice were intravenously injected with CD8a-sorted IEL, previously cultured for $24 \mathrm{~h}$ with IL-15/IL-15R complex recombinant protein (100ng/ml, Thermo Fisher Scientific) and retinoic acid $(100 \mathrm{ng} / \mathrm{ml})$. The efficiency of IEL transfer was assessed 4 weeks post transfer by flow cytometry. For IEL competitive adoptive transfer, mice were injected with a mix of WT and GzmA/B dKO IEL $\left(1 \times 10^{6}\right.$ cells in 100ul of PBS; $1: 1$ ratio). For Salmonella challenge experiments, Rag ${ }^{-/}$mice were transferred with $10^{6}$ WT or GzmA/B dKO IEL and, 4 weeks later, mice were orally challenged with SL1334 as described above.

\section{Flow cytometry}

The following murine monoclonal antibodies were used to detect cell surface markers: TCR $\beta$ [clone H57-597 (BioLegend)], TCRyठ [clone GL3 (BioLegend or eBioscience)], CD4 [clone RM4-5 (BioLegend)], CD8 $\alpha$ [clone 53-6.7 (BioLegend)], CD8 $\beta$ [clone H35-17.2 (eBioscience)], CD103 [clone 2E7 (BioLegend)], CD160 [clone 7H1 (BioLegend)],CD223 (LAG3) [clone eBioC9B7W (eBioscience)], CD85k (LILRB4) [clone H1.1 (BioLegend)], TIGIT [clone GIGD7 (BioLegend)], CD69 [clone H1.2F3 (eBioscience)], CD96 [clone 3.3 (BioLegend)], CD45 [clone 30-F11 (BioLegend)], Nkp46 [clone 29A1.4 (BioLegend)]. For intracellular staining, cells were fixed with $2 \%$ PFA at $37^{\circ} \mathrm{C}$ for 10 min before permeabilization with permabilization buffer (eBioscience). Cells were incubated with the following murine monoclonal antibodies: GzmB [clone GB12 (eBioscience)], GzmA [clone GzA-3G8.5 (eBioscience)], FoxP3 [clone FJK-16s (eBioscience)]. For CD107 surface marker staining, cells were incubated with brefeldin $A 2 h$ at $37^{\circ} \mathrm{C}$ before surface stain with a mix of CD107a (LAMP1) [clone 1D4B (BioLegend)] and CD107b (Mac-3) [clone M384 (BioLegend)].

\section{mLN and spleen cell suspension}

Mice were culled by $\mathrm{CO}_{2}$ and tissues were collected. $\mathrm{mLN}$ were crushed through a $70 \mu \mathrm{m}$ strainer in RPMI medium (RPMI; 10\% FBS; 1\% glutamine; 1\% penicillin-streptomycin). Spleens were crushed through a $70 \mu \mathrm{m}$ strainer and red blood cells were lysed, and remaining cells taken for flow cytometric analyses.

\section{MODE-K infection and CFU assays}

Ampicillin-resistant SL1334-Lux were grown as described in the above sections and were resuspended in infection medium (DMEM + 1\% BSA, without antibiotics). MODE-K (kind gift of. D. Kaiserlian, Lyon) were seeded overnight (in DMEM supplemented with $10 \%$ FBS and $1 \%$ L- 
bioRxiv preprint doi: https://doi.org/10.1101/2021.11.07.467595; this version posted November 23, 2021. The copyright holder for this preprint (which was not certified by peer review) is the author/funder, who has granted bioRxiv a license to display the preprint in perpetuity. It is made available under aCC-BY 4.0 International license.

Gzms in intestinal infection

glutamine, no antibiotics) and infected at a multiplicity of infection (MOI) of 10. For intracellular growth assessment, bacteria were pre-mixed with CD8 $\alpha^{+}$purified IEL (1:10 bacteria-effector ratio), or left untreated, for $15 \mathrm{~min}$ and the mix was then added to the MODE-K, for $1 \mathrm{~h}$. Cells were washed and treated with $50 \mu \mathrm{g} / \mathrm{ml}$ of gentamicin in infection medium to kill off extracellular bacteria for $30 \mathrm{~min}$ (90 min time point) and then kept in $12.5 \mu \mathrm{g} / \mathrm{ml}$ of gentamicin. At indicated time points, bioluminescence was measured in a PHERAstar plate reader. To assess bacteria extracellular growth in presence of IEL, SL1334-lux were mixed with IEL (1:10 bacteria-effector ratio) and bioluminescence was measured at indicated time point. For assessment of intracellular growth of Salmonella, MODE-K cells were first infected with SL1334-lux (MOI of 10 ) for $1 \mathrm{~h}$, washed and treated with $50 \mu \mathrm{g} / \mathrm{ml}$ of gentamicin. Then CD8 $\alpha$ sorted IEL (1:10 bacteria-effector ratio) along with $100 \mathrm{ng} / \mathrm{ml}$ of IL-15/IL-15R complex recombinant protein were added. At indicated time points, bioluminescence was measured using a PHERAstar plate reader.

After 24h, survival of the MODE-K cells was assessed, by first washing the cells in PBS, to remove IEL and bacteria, then staining living cells for 20 minutes with $100 \mu \mathrm{l} /$ well of Crystal Violet $(0.75 \mathrm{~g}$ in $12.5 \mathrm{ml}$ water and $37.5 \mathrm{ml}$ methanol). After washing with water, the Crystal Violet was solubilised by adding $200 \mu \mathrm{l} /$ well of methanol. The solubilised Crystal Violet was quantified by reading absorbance at $570 \mathrm{~nm}$. The absorbance was normalised to the absorbance in infected MODE-K cells without IEL, to calculate the percentage cell death, using the formula : cell death $(\%)=100^{*}\left[\mathrm{Abs}\left(\mathrm{MODE}-\mathrm{K}_{\mathrm{inf}}\right)-\right.$ Abs(MODE-K $\left.K_{\text {inf }+1 E L}\right) / A b s\left(M O D E-K_{\text {inf }}\right)$.

\section{Immunofluorescence and imaging}

Small intestinal tissue from GzmA sKO or GzmB sKO mouse or their WT littermates were flushed once with cold HBSS and once with a room-temperature fixative (2\% paraformaldehyde in PBS, $\mathrm{pH}=7.4)$, and small $(0.8-1 \mathrm{~cm})$ fragments from jejunum or ileum were excised and incubated at room temperature in $10 \mathrm{ml}$ of fresh fixative for 2-3 hours with slow agitation. The tissues were then washed three times with $50 \mathrm{mM}$ ammonium chloride in PBS and incubated overnight in PBS containing $30 \%$ sucrose, before embedding in OCT (Agar Scientific) on dry ice and stored below $-18^{\circ} \mathrm{C} .15 \mu \mathrm{m}$ sections of the frozen tissues were rehydrated in PBS, permeabilised for 10-15 min with 1\% NP40 in PBS, blocked for 1 hour with PBS containing 2\% BSA and $0.1 \%$ Triton-X100 and stained with a mixture of Alexa Fluor 647-labelled mouse anti-Granzyme A ab (Santa Cruz, clone 3G8.5, sc33692AF647, at 1:500 dilution) and goat anti-Granzyme B ab (R\&D systems, AF1865, at 1:50 dilution) in above blocking solution overnight at $+4^{0} \mathrm{C}$. After 5 washes with PBS, the slides were stained for 1 hour with Alexa Fluor 647-conjugated donkey anti-mouse, Alexa Fluor 488- or Rhodamine Red-Xconjugated donkey anti-goat antibodies (Jackson ImmunoResearch, at 1:500 dilution) and Alexa Fluor 568 phalloidin (Invitrogen, at 1:75 dilution) or acti-stain 488 phalloidin (Cytoskeleton, Inc, at $1: 75$ dilution) in the blocking solution. After 4 additional PBS washes, the tissues were stained with $1 \mu \mathrm{g} / \mathrm{ml}$ DAPI in PBS for $10 \mathrm{~min}$, washed in PBS and mounted using Vectashield Vibrance antifade 
bioRxiv preprint doi: https://doi.org/10.1101/2021.11.07.467595; this version posted November 23, 2021. The copyright holder for this preprint (which was not certified by peer review) is the author/funder, who has granted bioRxiv a license to display the preprint in perpetuity. It is made available under aCC-BY 4.0 International license.

Gzms in intestinal infection

mounting media (Vector Laboratories). Tissues were imaged using confocal Zeiss LSM 710 or LSM 880 microscope operated by Zen software using 63x/1.4NA oil immersion objective. Where indicated, serial optical sections were collected throughout the entire thickness of the tissue, and maximal intensity projections from the sections spanning selected IELs were generated in ImageJ.

\section{Plasma preparation and cytokine level measurement}

Mice were euthanized by $\mathrm{CO}_{2}$. Blood was collected by intracardiac puncture and transferred into tubes containing $5 \mathrm{mM}$ EDTA. Blood was centrifuged for $15 \mathrm{~min}$ at $800 \mathrm{~g}$, and plasma was collected. Plasma cytokine levels were assessed using mouse ProcartaPlex cytokine and chemokine panels (ThermoFisher Scientific), according to the manufacturer's instructions. Data were acquired using the Luminex 200 analyser.

\section{IEL:enteroid co-cultures}

To generate the enteroids, small intestine from a C57BL/6J mouse were longitudinally cut to scrape off the villi using a coverslip and washed with cold PBS. The small intestine was cut into small 3$5 \mathrm{~mm}$ pieces and incubated in PBS containing $1 \mathrm{mM}$ EDTA for 20 minutes at $4^{\circ} \mathrm{C}$ on a tube roller. After being filtered through a $100 \mu \mathrm{m}$ sieve, the pieces were further incubated in PBS supplemented with $5 \mathrm{mM}$ EDTA for 30 minutes at $4^{\circ} \mathrm{C}$. The tissue fragments were transferred into PBS and vigorously shaken for one minute. Isolated crypts were centrifuged for 3 minutes at $200 \mathrm{~g}$, mixed with Matrigel (Corning) and plated in a 24-well plate in ENR medium (Advanced DMEM/F12

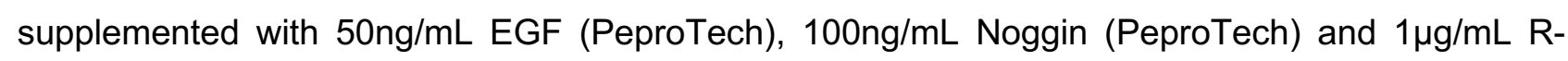
spondin-1 (PeproTech))

For IEL-enteroid co-culture, two-day-old enteroids were released from the Matrigel and incubated with WT or GzmA/B dKO purified CD8 $\alpha^{+}$IELs that were labelled with cell tracking dye CFSE, for 30 minutes at $37^{\circ} \mathrm{C}$ (at a ratio of 500 IELs to 1 enteroid) and then plated in an 8-well $\mu$-Slide ibiTreat (Ibidi) in ENR medium supplemented with $10 \mathrm{ng} / \mathrm{mL}$ soluble IL-15 and $100 \mathrm{U} / \mathrm{mL} \mathrm{IL}-2$. 48h later, live imaging of the co-culture was performed using Zeiss 710 confocal microscope system at $37^{\circ} \mathrm{C}$ and $10 \% \mathrm{CO}_{2}, 20 \mathrm{X}$ dry objective. $20 \mathrm{z}$-stacks with $3 \mu \mathrm{m}$ interval of the region of interest (ROI) were acquired for at least $90 \mathrm{~min}$. The mean track speed and track displacement length were analysed using Imaris by creating a Spot function that detected cells with diameter from $7.5 \mu \mathrm{m}-8 \mu \mathrm{m}$.

\section{Statistical analysis}

Data analysis was done using GraphPad Prism v9. For bacterial counts, ranks were compared using the Mann-Whitney U-test. For all other comparisons, two-way ANOVA was used, with multiple comparisons using Sidak's multiple comparisons tests, unless otherwise stated in the figure legend. Standard annotations were used to denote significance: * $p<0.05$, ${ }^{* *} p<0.01,{ }^{* * *} p<0.001$, *** $\mathrm{p}<0.0001$. 
bioRxiv preprint doi: https://doi.org/10.1101/2021.11.07.467595; this version posted November 23, 2021. The copyright holder for this preprint (which was not certified by peer review) is the author/funder, who has granted bioRxiv a license to display the preprint in perpetuity. It is made available under aCC-BY 4.0 International license.

Gzms in intestinal infection

\section{REFERENCES}

Akeda T, Yamanaka K, Tsuda K, Omoto Y, Gabazza EC, Mizutani H. 2014. CD8+ T cell granzyme B activates keratinocyte endogenous IL-18. Arch Dermatol Res 306:125-130. doi:10.1007/s00403013-1382-1

Anderson CJ, Medina CB, Barron BJ, Karvelyte L, Aaes TL, Lambertz I, Perry JSA, Mehrotra P, Gonçalves A, Lemeire K, Blancke G, Andries V, Ghazavi F, Martens A, van Loo G, Vereecke L, Vandenabeele P, Ravichandran KS. 2021. Microbes exploit death-induced nutrient release by gut epithelial cells. Nature 596:262-267. doi:10.1038/s41586-021-03785-9

Arias M, Martínez-Lostao L, Santiago L, Ferrandez A, Granville DJ, Pardo J. 2017. The Untold Story of Granzymes in Oncoimmunology: Novel Opportunities with Old Acquaintances. Trends in Cancer 3:407-422. doi:10.1016/j.trecan.2017.04.001

Barthel M, Hapfelmeier S, Quintanilla-Martínez L, Kremer M, Rohde M, Hogardt M, Pfeffer K, Rüssmann H, Hardt W-D. 2003. Pretreatment of Mice with Streptomycin Provides a Salmonella enterica Serovar Typhimurium Colitis Model That Allows Analysis of Both Pathogen and Host. Infect Immun 71:28392858. doi:10.1128/IAI.71.5.2839-2858.2003

Brenes AJ, Vandereyken M, James OJ, Watt H, Hukelmann J, Spinelli L, Dikovskaya D, Lamond AI, Swamy M. 2021. Tissue environment, not ontogeny, defines murine intestinal intraepithelial T lymphocytes. Elife 10:e70055. doi:10.7554/eLife.70055

Bumann D. 2002. Examination of Salmonella gene expression in an infected mammalian host using the green fluorescent protein and two-colour flow cytometry. Molecular Microbiology 43:1269-1283. doi:10.1046/j.1365-2958.2002.02821.x

Buzza MS, Zamurs L, Sun J, Bird CH, Smith AI, Trapani JA, Froelich CJ, Nice EC, Bird PI. 2005. Extracellular Matrix Remodeling by Human Granzyme B via Cleavage of Vitronectin, Fibronectin, and Laminin *. Journal of Biological Chemistry 280:23549-23558. doi:10.1074/jbc.M412001200

Cao X, Cai SF, Fehniger TA, Song J, Collins LI, Piwnica-Worms DR, Ley TJ. 2007. Granzyme B and Perforin Are Important for Regulatory T Cell-Mediated Suppression of Tumor Clearance. Immunity 27:635-646. doi:10.1016/j.immuni.2007.08.014

Dalton JE, Cruickshank SM, Egan CE, Mears R, Newton DJ, Andrew EM, Lawrence B, Howell G, Else KJ, Gubbels MJ, Striepen B, Smith JE, White SJ, Carding SR. 2006. Intraepithelial yס+ Lymphocytes Maintain the Integrity of Intestinal Epithelial Tight Junctions in Response to Infection. Gastroenterology 131:818-829. doi:10.1053/j.gastro.2006.06.003

Davies A, Lopez-Briones S, Ong H, O'Neil-Marshall C, Lemonnier FA, Nagaraju K, Metcalf ES, Soloski MJ.

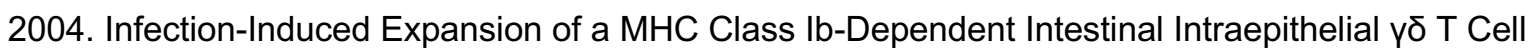
Subset. J Immunol 172:6828-6837. doi:10.4049/jimmunol.172.11.6828

Edelblum KL, Shen L, Weber CR, Marchiando AM, Clay BS, Wang Y, Prinz I, Malissen B, Sperling AI, Turner JR. 2012. Dynamic migration of $y \delta$ intraepithelial lymphocytes requires occludin. Proceedings of the National Academy of Sciences 109:7097-7102. doi:10.1073/pnas.1112519109

Edelblum KL, Singh G, Odenwald MA, Lingaraju A, El Bissati K, McLeod R, Sperling Al, Turner JR. 2015. үס Intraepithelial Lymphocyte Migration Limits Transepithelial Pathogen Invasion and Systemic Disease in Mice. Gastroenterology 148:1417-1426. doi:10.1053/j.gastro.2015.02.053 
bioRxiv preprint doi: https://doi.org/10.1101/2021.11.07.467595; this version posted November 23, 2021. The copyright holder for this preprint (which was not certified by peer review) is the author/funder, who has granted bioRxiv a license to display the preprint in perpetuity. It is made available under aCC-BY 4.0 International license.

Gzms in intestinal infection

Garzón-Tituaña M, Sierra-Monzón JL, Comas L, Santiago L, Khaliulina-Ushakova T, Uranga-Murillo I, Ramirez-Labrada A, Tapia E, Morte-Romea E, Algarate S, Couty L, Camerer E, Bird PI, Seral C, Luque P, Paño-Pardo JR, Galvez EM, Pardo J, Arias M. 2021. Granzyme A inhibition reduces inflammation and increases survival during abdominal sepsis. Theranostics 11:3781-3795. doi:10.7150/thno.49288

Godinez I, Haneda T, Raffatellu M, George MD, Paixão TA, Rolán HG, Santos RL, Dandekar S, Tsolis RM, Bäumler AJ. 2008. T Cells Help To Amplify Inflammatory Responses Induced by Salmonella enterica Serotype Typhimurium in the Intestinal Mucosa. Infection and Immunity 76:2008-2017. doi:10.1128/IAI.01691-07

Hendel A, Hiebert PR, Boivin WA, Williams SJ, Granville DJ. 2010. Granzymes in age-related cardiovascular and pulmonary diseases. Cell Death Differ 17:596-606. doi:10.1038/cdd.2010.5

Hildebrand D, Bode KA, Rieß D, Cerny D, Waldhuber A, Römmler F, Strack J, Korten S, Orth JHC, Miethke T, Heeg K, Kubatzky KF. 2014. Granzyme A Produces Bioactive IL-1 $\beta$ through a Nonapoptotic Inflammasome-Independent Pathway. Cell Reports 9:910-917. doi:10.1016/j.celrep.2014.10.003

Hoytema van Konijnenburg DP, Reis BS, Pedicord VA, Farache J, Victora GD, Mucida D. 2017. Intestinal Epithelial and Intraepithelial T Cell Crosstalk Mediates a Dynamic Response to Infection. Cell 171:783-794.e13. doi:10.1016/j.cell.2017.08.046

Hu MD, Ethridge AD, Lipstein R, Kumar S, Wang Y, Jabri B, Turner JR, Edelblum KL. 2018. Epithelial IL-15 Is a Critical Regulator of $\gamma \delta$ Intraepithelial Lymphocyte Motility within the Intestinal Mucosa. The Journal of Immunology 201:747-756. doi:10.4049/jimmunol.1701603

Hu MD, Golovchenko NB, Kelly TJ, Agos J, Zeglinski MR, Bonder EM, Granville DJ, Watson AJM, Edelblum KL. 2021. $y \delta$ intraepithelial lymphocytes facilitate pathological epithelial cell shedding via CD103mediated granzyme release. 1-29. doi:10.1101/2021.01.20.427150

Jaime-Sánchez P, Catalán E, Uranga-Murillo I, Aguiló N, Santiago L, M Lanuza P, de Miguel D, A Arias M, Pardo J. 2018. Antigen-specific primed cytotoxic T cells eliminate tumour cells in vivo and prevent tumour development, regardless of the presence of anti-apoptotic mutations conferring drug resistance. Cell Death Differ 25:1536-1548. doi:10.1038/s41418-018-0112-9

James OJ, Vandereyken M, Marchingo JM, Singh F, Bray SE, Wilson J, Love AG, Swamy M. 2021. IL-15 and PIM kinases direct the metabolic programming of intestinal intraepithelial lymphocytes. Nat Commun 12:4290. doi:10.1038/s41467-021-24473-2

James OJ, Vandereyken M, Swamy M. 2020. Isolation, Characterization, and Culture of Intestinal Intraepithelial Lymphocytes. Methods in molecular biology (Clifton, NJ) 2121:141-152. doi:10.1007/978-1-0716-0338-3_13

Jong LC de, Crnko S, Broeke T ten, Bovenschen N. 2021. Noncytotoxic functions of killer cell granzymes in viral infections. PLOS Pathogens 17:e1009818. doi:10.1371/journal.ppat.1009818

Kaiserman D, Bird CH, Sun J, Matthews A, Ung K, Whisstock JC, Thompson PE, Trapani JA, Bird PI. 2006. The major human and mouse granzymes are structurally and functionally divergent. $J$ Cell Biol 175:619-630. doi:10.1083/jcb.200606073 
bioRxiv preprint doi: https://doi.org/10.1101/2021.11.07.467595; this version posted November 23, 2021. The copyright holder for this preprint (which was not certified by peer review) is the author/funder, who has granted bioRxiv a license to display the preprint in perpetuity. It is made available under aCC-BY 4.0 International license.

Gzms in intestinal infection

Klose CSN, Kiss EA, Schwierzeck V, Ebert K, Hoyler T, d'Hargues Y, Göppert N, Croxford AL, Waisman A, Tanriver Y, Diefenbach A. 2013. A T-bet gradient controls the fate and function of CCR6-RORYt+ innate lymphoid cells. Nature 494:261-265. doi:10.1038/nature11813

Kurioka A, Ussher JE, Cosgrove C, Clough C, Fergusson JR, Smith K, Kang Y-H, Walker LJ, Hansen TH, Willberg CB, Klenerman P. 2015. MAIT cells are licensed through granzyme exchange to kill bacterially sensitized targets. Mucosal Immunol 8:429-440. doi:10.1038/mi.2014.81

Lane MC, Alteri CJ, Smith SN, Mobley HLT. 2007. Expression of flagella is coincident with uropathogenic Escherichia coli ascension to the upper urinary tract. Proc Natl Acad Sci U S A 104:16669-16674. doi:10.1073/pnas.0607898104

Lee S-J, Dunmire S, McSorley SJ. 2012. MHC class-I-restricted CD8 T cells play a protective role during primary Salmonella infection. Immunology Letters 148:138-143. doi:10.1016/j.imlet.2012.10.009

Li Z, Zhang C, Zhou Z, Zhang Jianhua, Zhang Jian, Tian Z. 2012. Small Intestinal Intraepithelial Lymphocytes Expressing CD8 and T Cell Receptor $y \delta$ Are Involved in Bacterial Clearance during Salmonella enterica Serovar Typhimurium Infection. Infection and immunity 80:565-574. doi:10.1128/IAI.05078-11

Martínez-Lostao L, Anel A, Pardo J. 2015. How Do Cytotoxic Lymphocytes Kill Cancer Cells? Clin Cancer Res 21:5047-5056. doi:10.1158/1078-0432.CCR-15-0685

Metkar SS, Menaa C, Pardo J, Wang B, Wallich R, Freudenberg M, Kim S, Raja SM, Shi L, Simon MM, Froelich CJ. 2008. Human and Mouse Granzyme A Induce a Proinflammatory Cytokine Response. Immunity 29:720-733. doi:10.1016/j.immuni.2008.08.014

Omoto Y, Yamanaka K, Tokime K, Kitano S, Kakeda M, Akeda T, Kurokawa I, Gabazza EC, Tsutsui H, Katayama N, Yamanishi K, Nakanishi K, Mizutani H. 2010. Granzyme B is a novel interleukin-18 converting enzyme. J Dermatol Sci 59:129-135. doi:10.1016/j.jdermsci.2010.05.004

Pardo J, Bosque A, Brehm R, Wallich R, Naval J, Müllbacher A, Anel A, Simon MM. 2004. Apoptotic pathways are selectively activated by granzyme $A$ and/or granzyme $B$ in CTL-mediated target cell lysis. Journal of Cell Biology 167:457-468. doi:10.1083/jcb.200406115

Pardo J, Wallich R, Martin P, Urban C, Rongvaux A, Flavell RA, Müllbacher A, Borner C, Simon MM. 2008. Granzyme B-induced cell death exerted by ex vivo CTL: discriminating requirements for cell death and some of its signs. Cell Death Differ 15:567-579. doi:10.1038/sj.cdd.4402289

Prakash MD, Munoz MA, Jain R, Tong PL, Koskinen A, Regner M, Kleifeld O, Ho B, Olson M, Turner SJ, Mrass P, Weninger W, Bird PI. 2014. Granzyme B Promotes Cytotoxic Lymphocyte Transmigration via Basement Membrane Remodeling. Immunity 41:960-972. doi:10.1016/j.immuni.2014.11.012

Rauch I, Deets KA, Ji DX, von Moltke J, Tenthorey JL, Lee AY, Philip NH, Ayres JS, Brodsky IE, Gronert K, Vance RE. 2017. NAIP-NLRC4 Inflammasomes Coordinate Intestinal Epithelial Cell Expulsion with Eicosanoid and IL-18 Release via Activation of Caspase-1 and -8. Immunity 46:649-659. doi:10.1016/j.immuni.2017.03.016

Roberts SJ, Smith AL, West AB, Wen L, Findly RC, Owen MJ, Hayday AC. 1996. T-cell alpha beta + and gamma delta + deficient mice display abnormal but distinct phenotypes toward a natural, widespread infection of the intestinal epithelium. PNAS 93:11774-11779. doi:10.1073/pnas.93.21.11774 
Gzms in intestinal infection

Santiago L, Castro M, Sanz-Pamplona R, Garzón M, Ramirez-Labrada A, Tapia E, Moreno V, Layunta E, Gil-Gómez G, Garrido M, Peña R, Lanuza PM, Comas L, Jaime-Sanchez P, Uranga-Murillo I, del Campo R, Pelegrín P, Camerer E, Martínez-Lostao L, Muñoz G, Uranga JA, Alcalde A, Galvez EM, Ferrandez A, Bird PI, Metkar S, Arias MA, Pardo J. 2020. Extracellular Granzyme A Promotes Colorectal Cancer Development by Enhancing Gut Inflammation. Cell Reports 32:107847. doi:10.1016/j.celrep.2020.107847

Sellin ME, Müller AA, Felmy B, Dolowschiak T, Diard M, Tardivel A, Maslowski KM, Hardt W-D. 2014. Epithelium-Intrinsic NAIP/NLRC4 Inflammasome Drives Infected Enterocyte Expulsion to Restrict Salmonella Replication in the Intestinal Mucosa. Cell Host \& Microbe 16:237-248. doi:10.1016/j.chom.2014.07.001

Shires J, Theodoridis E, Hayday AC. 2001. Biological insights into TCRgammadelta+ and TCRalphabeta+ intraepithelial lymphocytes provided by serial analysis of gene expression (SAGE). Immunity 15:419-434.

Sittka A, Pfeiffer V, Tedin K, Vogel J. 2007. The RNA chaperone Hfq is essential for the virulence of Salmonella typhimurium. Mol Microbiol 63:193-217. doi:10.1111/j.1365-2958.2006.05489.x Turner CT, Lim D, Granville DJ. 2019. Granzyme B in skin inflammation and disease. Matrix Biology 7576:126-140. doi:10.1016/j.matbio.2017.12.005

van Daalen KR, Reijneveld JF, Bovenschen N. 2020. Modulation of Inflammation by Extracellular Granzyme A. Front Immunol 11:931. doi:10.3389/fimmu.2020.00931

Voskoboinik I, Whisstock JC, Trapani JA. 2015. Perforin and granzymes: function, dysfunction and human pathology. Nat Rev Immunol 15:388-400. doi:10.1038/nri3839

Zhou Z, He H, Wang K, Shi X, Wang Yupeng, Su Y, Wang Yao, Li D, Liu W, Zhang Y, Shen Lianjun, Han W, Shen Lin, Ding J, Shao F. 2020. Granzyme A from cytotoxic lymphocytes cleaves GSDMB to trigger pyroptosis in target cells. Science 368:eaaz7548. doi:10.1126/science.aaz7548 
Gzms in intestinal infection

\section{SUPPLEMENTARY INFORMATION}
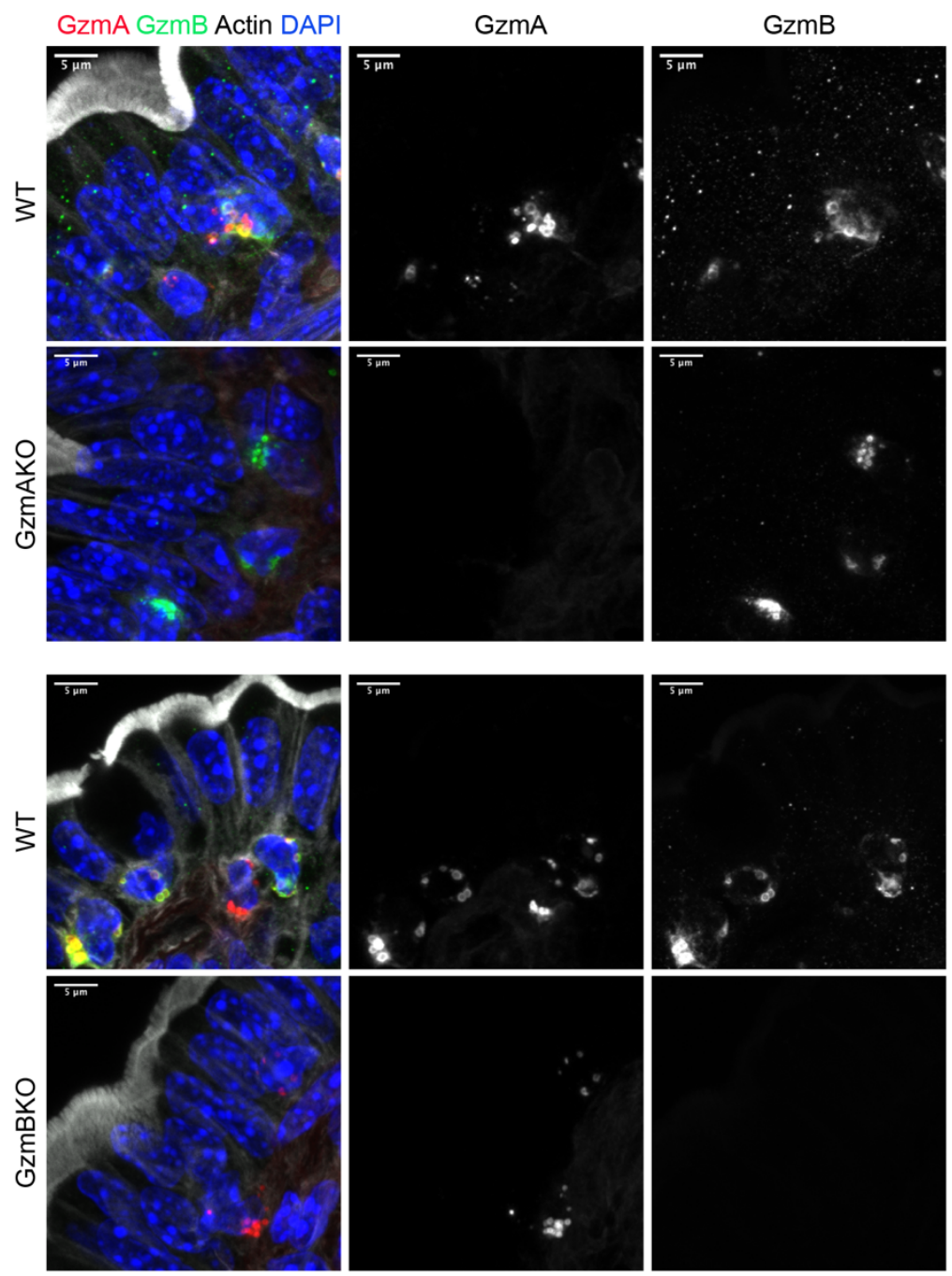

\section{Supplementary Figure 1}

The specificity of GzmA and GzmB immunostaining in intestinal tissues. Frozen ileum sections from GzmA $\mathrm{KO}$ (second row) or GzmB KO (fourth row) mice and their WT littermates (first row and third row, correspondingly) were co-stained for GzmA (middle panels, and red on left panels) and GzmB (right panels, and green on left panels) and counterstained with phalloidin to show actin (white on left panels) and DAPI to show nuclei (blue on left panels). Maximal intensity projections of high-magnification images from several optical sections are shown. Scale bar $=5 \mu \mathrm{m}$. For each $\mathrm{KO}$ - wt pair, tissues were prepared and stained in parallel, and images were acquired and processed identically. Note a complete absence of GzmA or GzmB staining in the corresponding KO tissues. 
Gzms in intestinal infection

suppl fig 2

A

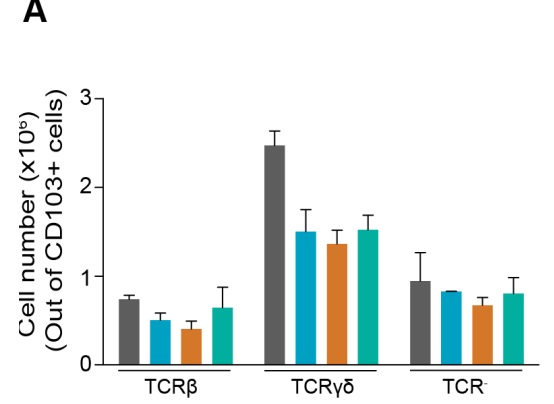

B

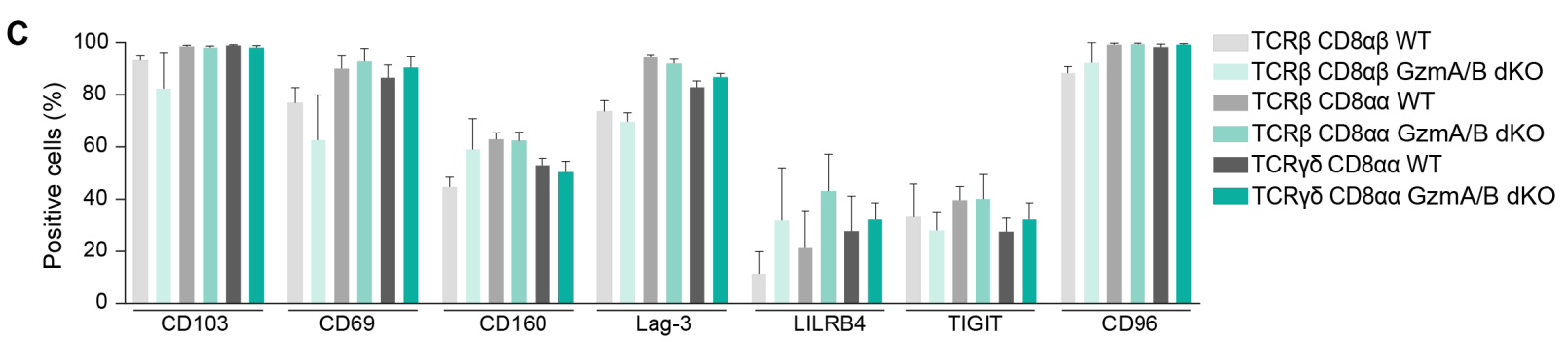

D
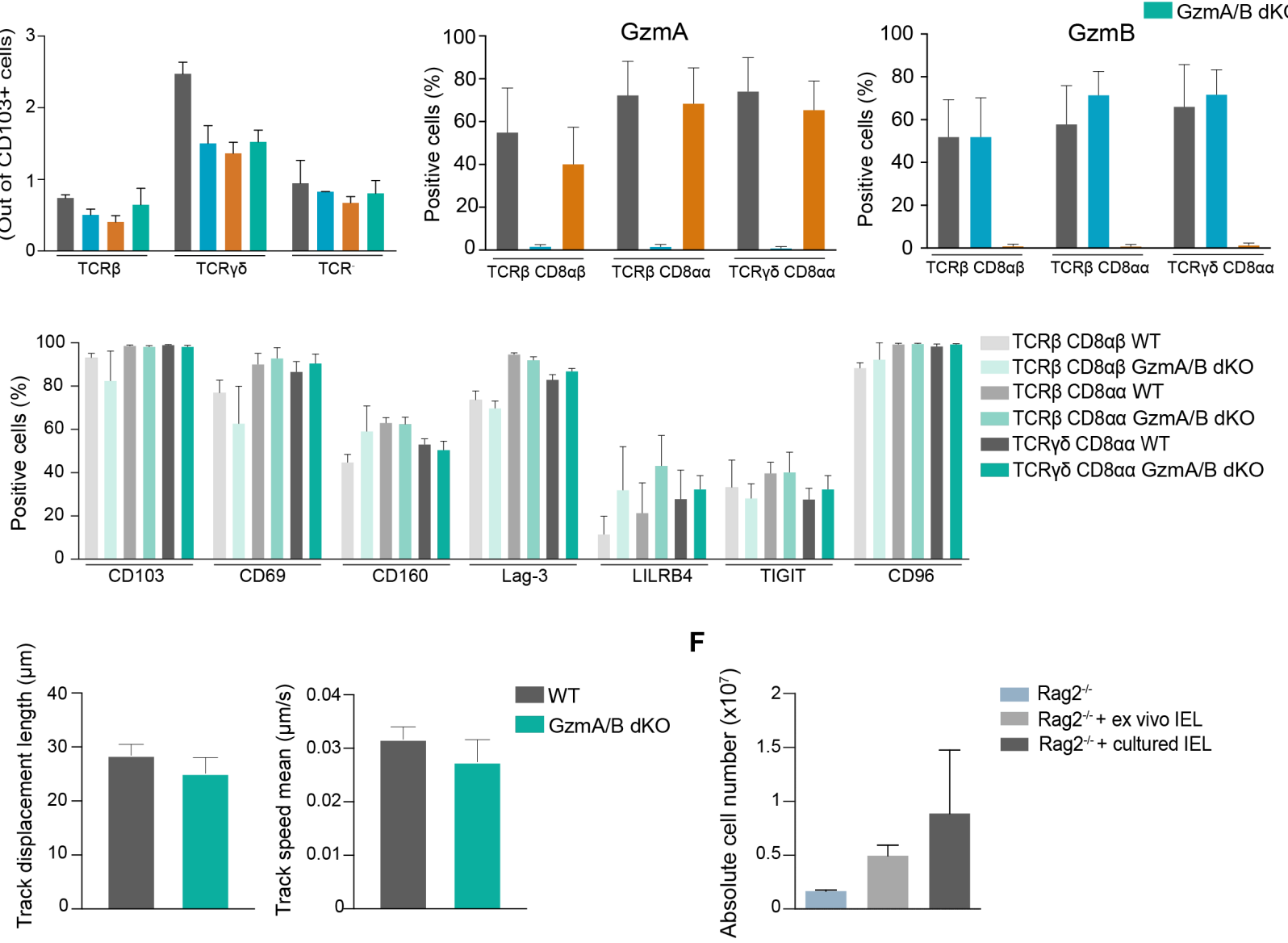

$\mathbf{F}$

G
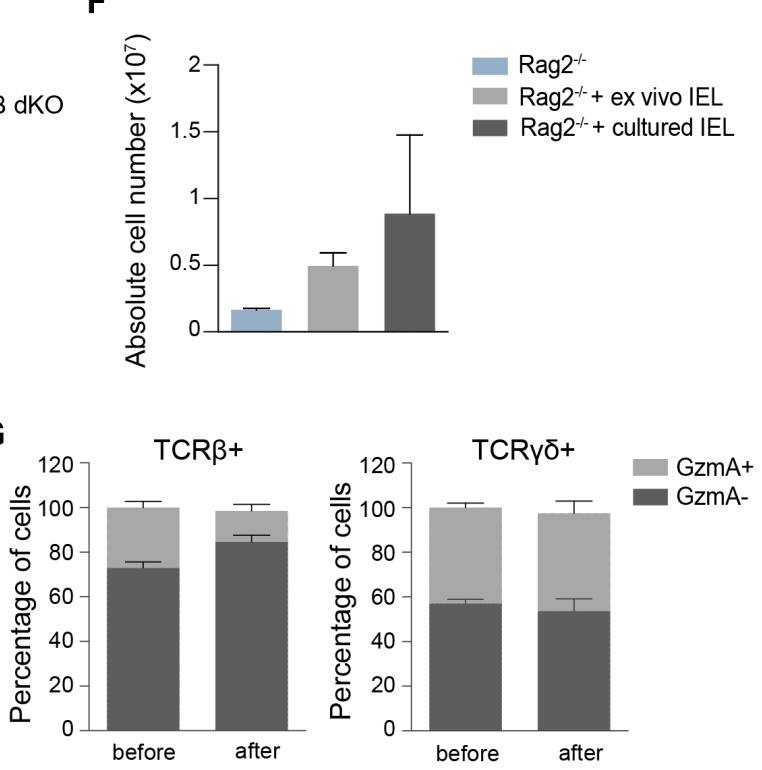

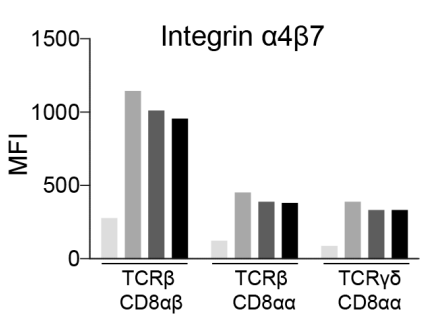

E

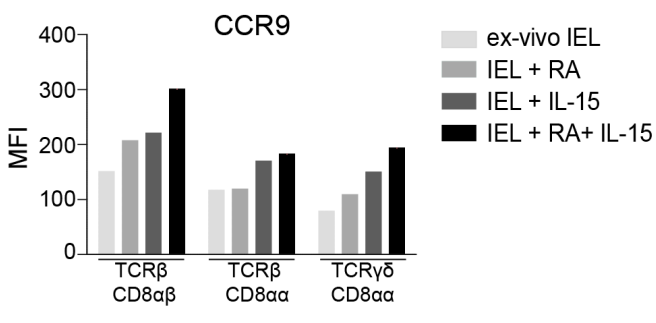

Supplementary Figure 2

A. Absolute numbers of CD103+ IEL in WT, GzmA sKO, GzmB sKO and GzmA/B dKO mice. B. Comparison of the percentage of GzmA (left) or GzmB (right) positive IEL in WT and Gzm sKO mice ( $n>5)$. C. Comparison of the percentage of positive WT and GzmA/B dKO IEL for CD103, CD69, CD160, Lag-3, LILRB4, TIGIT and CD96 surface markers ( $n>3$ ) D. Comparison of WT and GzmA/B dKO IEL displacement length (left) and speed (right) in IEL-enteroid co-cultures ( $n=3 /$ group). E. Comparison of the expression of CCR9 (upper panel) and a4ß7 (lower panel) on ex vivo IEL and IEL cultured with Retinoic acid and IL-15. F. Bar graph showing the 
bioRxiv preprint doi: https://doi org/10.1101/2021.11.07 467595; this version posted November 23,2021 . The copyright holder for this

preprint (which was not certified by peer review) is the author/funder, who has granted bioRxiv a license to display the preprint in perpetuity. It is made available under aCC-BY 4.0 International license.

Gzms in intestinal infection

number of $\mathrm{CD}_{4} 5^{+}$cells collected in the $\mathrm{SI}$ epithelium after ex-vivo $(n=3)$ or cultured $(n=2)$ IEL transfer into Rag2-- mice. G. Competitive transfer of cultured WT and GzmA/B dKO IEL into Rag2 ${ }^{-/-}$mice. WT and GzmA/B dKO IEL were mixed at a ratio of 1:1 before the transfer. Bar graphs show the ratio of GzmA positive cells in the TCR $\beta$ and TCRy $\delta$ population before the transfer $(n=2)$ and 4 weeks after the transfer $(n=4)$. All data are represented as mean \pm SEM. 
Gzms in intestinal infection
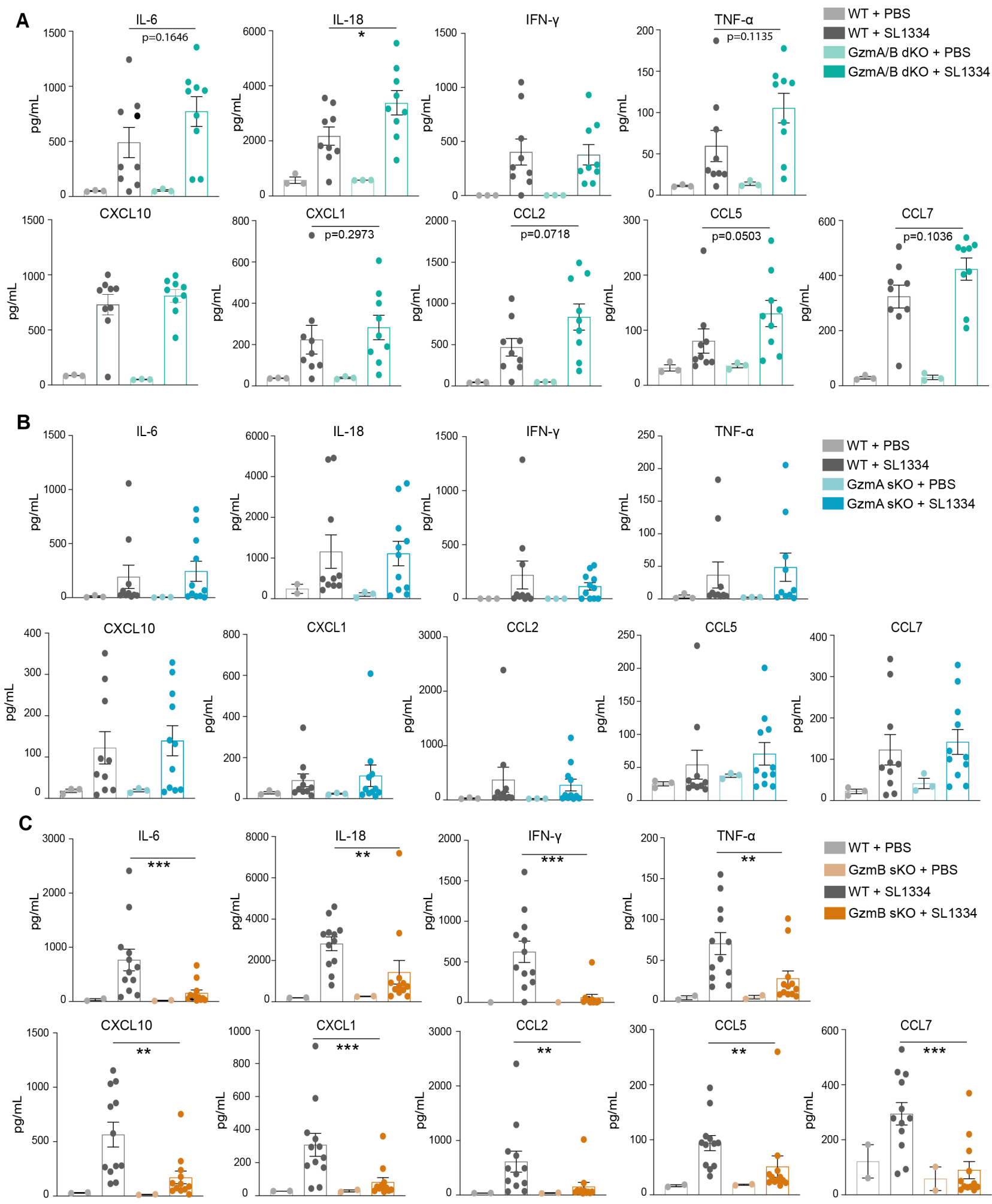

\section{Supplementary Figure 3}

Chemokine and cytokine levels in plasma of naïve and orally infected (A) GzmA/B dKO (n=9), (B) GzmA sKO $(n=12)$ and $(C)$ GzmB sKO $(n=12)$, compared to WT $(n>9)$ mice 5 days post Salmonella infection. Data were pooled from 2 independent experiments. All data are represented as mean \pm SEM. 
bioRxiv preprint doi: https://doi.org/10.1101/2021.11.07.467595; this version posted November 23, 2021. The copyright holder for this preprint (which was not certified by peer review) is the author/funder, who has granted bioRxiv a license to display the preprint in perpetuity. It is made available under aCC-BY 4.0 International license.

Gzms in intestinal infection
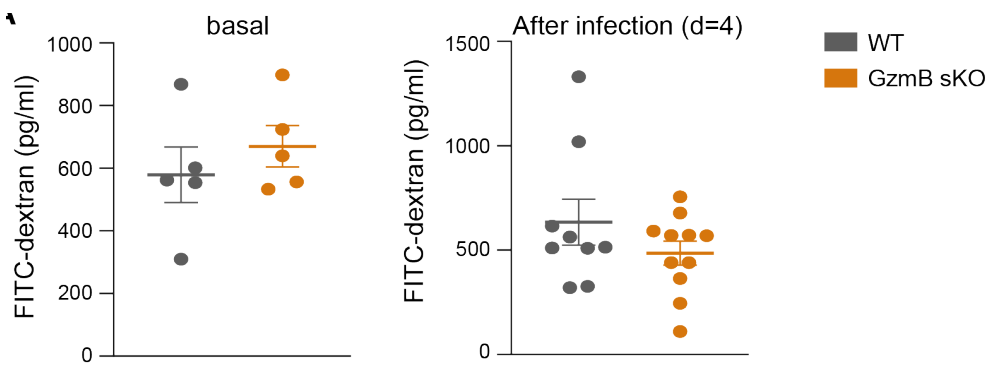

\section{Supplementary Figure 4}

Dot plots comparing intestinal permeability in naïve $(n=5)$ and orally $(n>9)$ infected WT and GzmB sKO mice. The concentration of the FITC dextran was measured in the serum of the mice $4 \mathrm{~h}$ after the gavage. 